\title{
Gradual retirement, financial incentives, and labour supply of older workers: Evidence from a stated preference analysis
}

\author{
Citation for published version (APA):
}

Elsayed, A., de Grip, A., Fouarge, D., \& Montizaan, R. (2018). Gradual retirement, financial incentives, and labour supply of older workers: Evidence from a stated preference analysis. Journal of Economic Behavior \& Organization, 150, 277-294. https://doi.org/10.1016/j.jebo.2018.01.012

Document status and date:

Published: 01/06/2018

DOI:

10.1016/j.jebo.2018.01.012

Document Version:

Publisher's PDF, also known as Version of record

\section{Document license:}

Taverne

Please check the document version of this publication:

- A submitted manuscript is the version of the article upon submission and before peer-review. There can be important differences between the submitted version and the official published version of record.

People interested in the research are advised to contact the author for the final version of the publication, or visit the DOI to the publisher's website.

- The final author version and the galley proof are versions of the publication after peer review.

- The final published version features the final layout of the paper including the volume, issue and page numbers.

Link to publication

\footnotetext{
General rights rights.

- You may freely distribute the URL identifying the publication in the public portal. please follow below link for the End User Agreement:

www.umlib.nl/taverne-license

Take down policy

If you believe that this document breaches copyright please contact us at:

repository@maastrichtuniversity.nl

providing details and we will investigate your claim.
}

Copyright and moral rights for the publications made accessible in the public portal are retained by the authors and/or other copyright owners and it is a condition of accessing publications that users recognise and abide by the legal requirements associated with these

- Users may download and print one copy of any publication from the public portal for the purpose of private study or research.

- You may not further distribute the material or use it for any profit-making activity or commercial gain

If the publication is distributed under the terms of Article $25 \mathrm{fa}$ of the Dutch Copyright Act, indicated by the "Taverne" license above, 


\title{
Gradual retirement, financial incentives, and labour supply of older workers: Evidence from a stated preference analysis
}

\author{
Ahmed Elsayed $^{\mathrm{a}, \mathrm{b}}$, Andries de Grip ${ }^{\mathrm{a}, \mathrm{b}, \mathrm{c}}$, Didier Fouarge $\mathrm{a}^{\mathrm{a}, \mathrm{b}, \mathrm{c}}$ \\ Raymond Montizaan ${ }^{\mathrm{a}, \mathrm{b}, \mathrm{c}, *}$ \\ a IZA, Bonn, Germany, Schaumburg-Lippe-Straße 5-9, Bonn, 53113, Germany \\ ${ }^{\mathrm{b}}$ ROA, Maastricht University: PO-box 616. Tongersestraat 53, Maastricht, MD 6200, Netherlands \\ ${ }^{\mathrm{c}}$ Netspar, PO-box 90153, Tilburg, LE 5000, Netherlands
}

\section{A R T I C L E I N F O}

\section{Article history:}

Received 10 March 2017

Revised 16 August 2017

Accepted 15 January 2018

Available online 1 February 2018

\section{JEL Classifications:}

J14

J26

\section{Keywords:}

Gradual retirement

Labour supply

Financial incentives

Stated preferences experiment

\begin{abstract}
A B S T R A C T
Using data from a stated preferences experiment in the Netherlands, we find that replacing full-time pension schemes with schemes that offer gradual retirement opportunities induce workers to retire one year later on average. Total lifetime labour supply, however, decreases by 3.4 months, because the positive effect of delayed retirement on labour supply is cancelled out by a reduction in working hours in the years before full retirement. The impact of gradual retirement schemes is, however, heterogeneous across groups of workers. Workers in bad health who gain access to gradual retirement postpone their retirement by 1.7 months more than workers in good health. This suggests that introduction of gradual retirement alleviates, to a certain extent, the health-related burden that employees in poor health may experience in carrying out their work. Nevertheless, introduction of gradual retirement reduces the total labour supply of both groups of workers. Financial incentives, either in terms of changing pension income or the price of leisure, also affect expected retirement age, but the impact of these financial incentives does not differ with the possibility of gradual retirement. Finally, we find that gradual retirement is not a preferred option among workers, as the large majority prefers full retirement.
\end{abstract}

(c) 2018 Elsevier B.V. All rights reserved.

\section{Introduction}

As a result of population ageing and declining fertility, many industrialised countries with 'pay-as-you-go' pension systems face a steady decrease in the ratio of contributing workers to inactive retirees who draw from these schemes. These underfunded systems will become financially unsustainable unless either the labour supply of older workers or productivity increases rapidly enough to compensate for the negative demographics. Most industrialised countries have therefore begun to implement major pension reforms aimed at increasing the labour supply of older workers to decrease the oldage dependency ratio. These reforms include, among others, decreases in the generosity of pension benefits and increases in the eligibility age for early and statutory retirement (Gruber and Wise, 1998; Duval, 2005; Mastrobuoni, 2009; Hanel, 2010; Kangas et al., 2010; Börsch-Supan, 2012; Staubli and Zweimüller, 2013). In addition, in several countries, gradual re-

\footnotetext{
* Corresponding author at: ROA / Maastricht University, PO-box 616, Tongersestraat 53, MD 6200, Maastricht, The Netherlands.

E-mail address: r.montizaan@maastrichtuniversity.nl (R. Montizaan).
} 
tirement schemes have been introduced, whereby workers do not end their career abruptly but rather in a stepwise fashion (Reday-Mulvey, 2000; Hutchens, 2010; Warren, 2015). ${ }^{1}$

Existing literature stresses that introduction of gradual retirement schemes can have major benefits both at the micro and macro levels (Kantarci and Van Soest 2008). At the micro level, gradual retirement schemes could improve lifetime utility, as they introduce the possibility of avoiding a pension shock following an abrupt transition from full-time work to fulltime retirement, and extend the choice set for older workers (Reday-Mulvey and Delsen 1996; Reday-Mulvey 2000). Gradual retirement could reduce the burden of work, and thereby reduce work-related stress and increase employee morale, enabling workers to keep working beyond an age at which they would otherwise have fully retired (Kantarci and Van Soest 2008). ${ }^{2}$ At the macro level, gradual retirement schemes may increase actual retirement age by facilitating work after the effective retirement age, thereby restraining early withdrawal from the labour market, provided that introduction of such schemes is accompanied by a pension structure with the right financial incentives. This would enhance the financial sustainability of current pension schemes. Gradual retirement could, however, also lead to a reduction in total labour supply when workers engage in early part-time retirement, where they would otherwise have chosen to continue to work on a full-time basis. The total effect on labour supply, and thus the sustainability of pension systems, therefore depends on which of these two effects is larger, making the net effect of the introduction of gradual retirement schemes on total labour supply ambiguous. This raises the question to what extent introduction of gradual retirement opportunities actually stimulates workers to continue working, and to what extent it can be expected to increase their total labour supply. Another question is whether the effects differ with the financial incentives provided by the pension system to postpone retirement, the burden of work, and workers' health.

This paper uses a stated preference approach to study the impact of a gradual retirement scheme on expected retirement age and total labour supply of Dutch public sector workers. We further investigate whether the effects differ with the financial incentives provided by the pension system, and explore heterogeneity in the impact of the introduction of gradual retirement opportunities on retirement preferences of workers with different personal and job characteristics. Our stated preference approach consists of six vignettes in which respondents get hypothetical (but realistic) retirement scenarios that either involve gradual or full retirement and that vary in terms of financial incentives (either in terms of changing the price of leisure or in terms of changing pension income). Respondents are asked to indicate at what age they would retire, and are subsequently asked to compare and rank the preferred choices they made when confronted with the different scenarios.

The main reason we use a stated rather than revealed preferences approach is that we want to estimate preferences for pension plans which do not yet exist or to which many workers so far do not have access. Previous empirical studies that focused on actual retirement decisions suggest that introduction of gradual retirement schemes may lead to postponement of retirement and are inconclusive about the impact on labour supply (e.g., Gustman and Steinmeier 2004; Gielen 2009; Machado and Portela 2012). Since these studies focused on actual retirement decisions, however, they did not identify all retirement options available to older workers, because the options that are not chosen cannot be observed, or because it is not clear which options workers would have chosen if they had the opportunity to choose (Kantarci and Van Soest 2008, 2013). The latter point is particularly relevant for studies on the impact of gradual retirement plans, since it is often unclear whether employers offer such plans, and if they do, which trajectory of earnings and pension incomes the plan includes. This is because gradual retirement arrangements are often based on informal agreements negotiated between an employee and the employer (Hutchens 2010). Moreover, it can be the case that employers who offer gradual retirement plans have other barriers that prevent workers from participating in these plans. Employers are often reluctant to promote gradual retirement due to higher fixed costs involved with part-time work, the adaptation to teamwork because of sharing of jobs and the risks of losing job-related skills caused by the reduction of working time (Hurd 1996). The use of revealed preferences therefore likely leads to an underestimation of the true labour supply effect of introducing gradual retirement. Our stated preferences approach circumvents this type of problem.

A further advantage of our stated preferences approach is that the included vignettes ensure that the choice alternatives are known to the researcher, and that the variation in choices is sufficiently large and, by construction, exogenous to preferences and actual pension entitlements. Because of this exogenous variation, the estimated effects are likely to be causal. This is also the reason why vignette studies are widely used in marketing research (e.g., Louviere et al., 2000), and transportation and environmental science (Hensher 1997). Vignette studies are also rapidly gaining ground in economics (see, e.g., Barsky et al. 1997; Revelt and Train 1998; Van Soest et al. 2007; Kantarci and Van Soest 2008; Braga et al., 2009; Benjamin et al., 2014; Van Soest and Vonkova 2014). Several studies have systematically examined the extent to which the

\footnotetext{
1 Gradual retirement schemes were first adopted over the past two decades in combination with early retirement programs, and were only later introduced as an alternative instrument to reduce early withdrawal from the labour market. Sweden was one of the first to adopt a gradual scheme in 1976 . In Denmark, a reform in 1987 aimed to promote gradual retirement by replacing the system of full early retirement with a part-time work regime. In Finland, a partial retirement scheme was introduced for wage earners aged 60 or older in the late 1980s. This was extended in the 1990 s to workers aged 56 or older and was further stimulated by additional incentives (e.g., tax cuts for firms). Germany, Austria, France, Belgium, and the Netherlands now also offer the option to enter gradual or partial retirement before or after the standard retirement age. Outside Europe, gradual retirement schemes have also been introduced. For example, the Australian government stimulated gradual retirement transitions by introducing 'transition to retirement' pensions in 2005, which allow older workers to reduce their working hours and access part of their superannuation savings in the form of a pension to supplement their labour income (Warren, 2015).

2 Allen et al. (2003) show that, for tenured faculty at the University of North Carolina, the odds of entering phased retirement are indeed strongly and inversely related to employee performance.
} 
hypothetical behaviour reported in vignette studies compares to actual behaviour and present convincing evidence that is supportive of the validity of the data generated through the use of vignettes (Peabody et al., 2000, 2004; Eifler 2007; Telser and Zweifel 2007).

We find that replacement of full-time retirement schemes with a gradual retirement scheme stimulates workers to retire full-time, on average, one year later. Nevertheless, labour supply significantly decreases by 3.4 months when workers have the gradual retirement option, as the positive effect of delayed retirement on labour supply is more than cancelled out by the reduction in working hours in the years preceding full retirement. This is due to the relatively long period that workers make use of gradual retirement schemes in which they work only half the time they would have worked if they had only the full-time retirement option. Gradual retirement thus has an asymmetric effect on the timing of various retirement stages by inducing an earlier start to the retirement process and not postponing full-time retirement enough to generate an offsetting effect on hours worked. The impact of the introduction of gradual retirement schemes is, however, heterogeneous across groups of workers. Workers in bad health who gain access to gradual retirement postpone their full-time retirement by 1.7 months more than employees in good health. Nevertheless, the introduction of gradual retirement reduces the total labour supply of both groups of workers. We further show that the positive impact of financial incentives to postpone retirement on workers' retirement expectations does not differ between gradual- and full-retirement options. Finally, our ranking analysis of workers' preference for the different scenarios shows that gradual retirement is not a preferred option among workers, as the large majority still prefers full retirement. Our results therefore suggest that introduction of gradual retirement opportunities in the Netherlands would not contribute to an increase in aggregate labour supply of workers close to retirement. We expect that these results are of particular interest to other Northern European countries which have similar pension systems. It should be noted, however, that we identify only the partial effect on the labour supply of workers close to retirement and do not claim that the decrease in labour supply due to gradual retirement would result in a reduction of total employment in the economy.

This study contributes to the literature on gradual retirement and labour supply of older workers in three ways. First, the correlation between gradual retirement opportunities and total labour supply is investigated by only a handful of empirical studies, which provide mixed results. While Gustman and Steinmeier (2004) found that abolishing minimum-hour constraints is associated with a small net increase in full-time equivalent employment, Gielen (2009) and Machado and Portela (2012) and Graf et al. (2011) found explorative suggestive evidence that labour supply of older workers is negatively associated with flexibility in work hours.

Second, this paper builds on two related studies by Van Soest et al. (2007) and Kantarci and Van Soest (2013). These studies, also using stated preferences experiments, show that many workers can be enticed to work part-time if they are given fair financial compensation, but also that many workers are more likely to choose full-time retirement over partial retirement. $^{3}$ Our study differs from these studies in several ways. Most importantly, we do not limit ourselves by studying only the impact of gradual retirement on retirement expectations, but focus particularly on its net impact on the expected total labour supply of workers who have the option of gradual retirement. In particular, for the oldest workers in our estimation sample, who are close to retirement, we might expect that these expected labour supply effects will translate into actual labour supply effects. ${ }^{4}$ A further advantage of our study is that the base scheme in our stated preference experiment is similar to the actual pension scheme of public sector workers in the Netherlands. While Van Soest et al. (2007) and Kantarci and Van Soest (2013) used highly stylized regimes that are not related to actual pension schemes in the Netherlands and do not allow for different durations of gradual retirement in their scenarios, our vignette regimes provide many more choice options, allowing for more realistic estimates of the effects of gradual retirement opportunities on the labour supply. Finally, we go beyond previous studies by showing that introduction of gradual retirement schemes in the Netherlands may have heterogeneous effects on the retirement age and labour supply of workers with health problems and physically demanding jobs.

This paper proceeds as follows. Section 2 describes the Dutch pension system. Section 3 describes the data, experimental design, and variables used in the analyses. Section 4 presents the main analyses. Finally, Section 5 summarises our findings and sets forth our conclusions.

\section{Dutch retirement system}

\subsection{Pillars of the Dutch retirement system}

Although our stated preference experiment used vignettes in which individuals were confronted with hypothetical pension schemes unrelated to their actual pension scheme, it is important to have a good overview of the Dutch retirement system. To what extent are the hypothetical pension schemes realistic to the respondents?

The Dutch pension system consists of three pillars (see De Grip et al. (2012; A. 2013) for more information). The first consists of a flat-rate public scheme (AOW) to which all citizens are entitled, regardless of whether they are employee,

\footnotetext{
3 Stated preference experiments have also been used in retirement studies which did not focus on gradual retirement (e.g., Van Soest and Vonkova, 2014).

4 Wadensjö (2006) showed descriptive evidence that introduction of a popular part-time pension scheme in Sweden was associated with an increase in the number of hours worked in Sweden, especially among women.
} 
self-employed, or never participated in the labour market. The AOW provides Dutch citizens with a pension benefit that guarantees $70 \%$ of the net minimum wage for a single household and 50\% for each partner in a couple (either married or officially living together). For decades, the eligibility age for the AOW was 65. Due to recent reforms in 2013 and 2015, the eligibility age for the AOW is gradually increasing to 66 years in 2018 and 67 in 2021. After 2021, the eligibility age will be linked to life expectancy in the Netherlands. If life expectancy increases further, so will the eligibility age for the AOW. Questions are raised in the ongoing discussion between social partners within the Netherlands as to whether further increases in the retirement age might have negative consequences especially for workers in heavy occupations. As a consequence, a recent proposal introduces a more flexible eligibility age for the AOW, including options for part-time retirement. ${ }^{5}$

The second pillar consists of supplementary earnings-related pensions. This is a defined-benefit type of pension for employees organized at the sector or firm level and is fully funded. Sector pensions are negotiated between unions and employer organizations at the sector or firm level and are in most cases set forth in collective agreements. Participation is mandatory, ensuring that each worker is covered by sector pensions. The Pensions and Savings Act (Pensioen en Spaarfondsenwet) until 2007 and the Pensions Act from 2007 onwards (Pensioenwet) dictate that the administration of the sector pension schemes in the second pillar is delegated to pension funds to which both employers and employees have to contribute. Pension benefits in the second pillar are based on the average wage workers have built up over their entire career. These average wage schemes have by now almost totally replaced the final salary schemes, based on employees' last wage. The second pillar pension can be used to retire early or late, before or after the eligibility age for the state pension. ${ }^{6}$ The earliest age people can claim second pillar pension benefits is 60 years, while the latest age is 70 years. Replacement rates depend on the age at retirement. Early retirement leads to lower benefits.

The third pillar includes all voluntarily built-up savings that are in addition to the first two pillars. Due to the wellestablished first two pillars of the Dutch pension system, the third pillar is less developed in the Netherlands than in other countries. The first two pillars combined already generate pension replacement rates that are amongst the most generous in the world (OECD 2017). ${ }^{7}$

In 2015, the first two pillars yielded a gross replacement rate of about $69 \%$ (of the average wage) when a typical worker in the public sector retired full-time at age 64 . This worker experienced an accrual rate of approximately $5 \%$ for each year he or she retires earlier (people can retire from 60 years onwards) or later (until age 70). This implies that the gross replacement rate would be about $65 \%$ when retiring at age 63 , approximately $80 \%$ when retiring at age 66 (the new eligibility age for the AOW in 2018), and approximately $99 \%$ when retiring at age $70 .^{8}$

\subsection{Part-time retirement options in the Netherlands}

Employees in the Netherlands have the option to retire part-time with an actuarially fair impact on their pension benefits. Part-time pension benefits are part of the second pillar of the Dutch pension system. Employees have the opportunity to decide together with their employer how much they reduce their working hours. Part-time pensions are, however, only possible in steps of at least $10 \%$ of full-time work. On average, Dutch employees who retire part-time reduce their working hours by 50\% (ROA Public Sector Survey 2014). When employees in the Netherlands decide to retire part-time, they receive a salary for the days worked and pension benefits for the rest of the full-time working week. Thus, they still build up pension rights for the part of the week they work. Because workers draw from their pension and due to the fact that they contribute over a smaller salary, their pensions will be lower than those of workers who continued working full-time. A part-time pension is only possible from age 60 until five years after workers reach pensionable age (which was 65 at the moment when our experiment was conducted).

\section{Data and experimental design}

\subsection{Data collection}

The Dutch public sector's pension fund provided us with 7520 randomly selected e-mail addresses of Dutch public sector employees born between 1952 and 1975. In the first week of April 2015, we sent an e-mail to these employees containing the link to a web-based survey (the ROA Public Sector Survey 2015) with questions on individual and job characteristics, alternative sources of income after retirement, and partner characteristics. Moreover, the survey included the stated preferences experiment we use to investigate workers' final age of retirement and labour supply until retirement under full-time

\footnotetext{
5 https://www.fnv.nl/site/nieuws/webassistent/HarrieLindelauff/fnvplan-flexibele-aow-voor-eerlijk-stoppen-met-werken/10puntenplanflexibeleaow.pdf.

${ }^{6}$ Although compensation for inflation is the default for supplementary earnings-related pensions, it has not been given in the last few years, due to the rising ratio between liabilities and assets of almost all pension funds.

7 The net pension replacement rates in Austria, Hungary, Spain, Portugal, Luxembourg, and the Slovak Republic are rather similar to those in the Netherlands.

8 This is under the condition that workers work full-time and have no gaps in yearly contributions to the public sector's pension fund.
} 
and gradual retirement schemes and different sets of financial incentives. In total, 1760 working individuals completed the survey. $^{9}$

\subsection{Experimental design}

This stated preference experiment used vignettes in which individuals were confronted with various hypothetical, yet realistic pension schemes. The stated preference experiment was introduced by a short text explaining the topic, after which employees were assigned to six vignettes representing the pension scheme scenarios (involving either gradual or full retirement), including different financial incentives and containing a set of retirement ages and related income replacement rates (expressed as a percentage of current net income). The way we present the pension schemes closely resembles the way the pension fund reports actual replacement rates at retirement age to its clients, although the pension schemes in the vignettes are simplified versions of the pension system, to keep the stated preference experiment comprehensible. For each scenario, respondents were asked which retirement age and associated replacement rate they prefer, making it possible to quantify how changes in financial incentives affect gradual and full-time retirement age. Figure A1 in the Appendix shows the introductory text and two examples of the vignettes.

We designed a total of ten pension scheme scenarios with different retirement ages and replacement rate combinations. Each respondent had to respond to two baseline scenarios: one that allows workers to retire only full-time and another that allows workers to retire gradually. The replacement rates in both baseline scenarios closely match those applied to an average public sector employee in the Netherlands at the time of the survey, with actuarially fair accruals of $5 \%$ for fulltime employment and $2.5 \%$ for part-time employment, and a $90 \%$ replacement rate upon retirement at age 68 for regular retirement, and at age 70 for gradual retirement (see the discussion on the Dutch pension system in Section 2).

The other eight scenarios differ from one another in terms of the incentives for continued employment provided by the retirement scheme. We implement a price of leisure type of incentive (accruals of $7.5 \%$ or $10 \%$ for an additional year of employment), and a pension income type of incentive (decreasing pension income at all ages by 5\% or $10 \%$ ). Four of these pension scheme scenarios allow workers to choose their preferred age of full-time retirement, while the other scenarios allow for gradual retirement with a specific number of years of part-time employment before full retirement. ${ }^{10}$ Apart from the baseline scenarios, two regular and two gradual retirement scenarios were randomly assigned to each respondent. Also, the order in which the scenarios were presented to the respondents was randomised.

Table 1 shows the ten pension scenarios with their combinations of retirement age and replacement rate. ${ }^{11}$ Scenario 1 is the full-time baseline scenario. It offers a replacement rate of $90 \%$ of net wage if the individual chooses to retire at age 68. For each additional year of work, the replacement rate increases by 5 percentage points. Scenarios 2 and 3 increase the price of leisure incentive. For each additional year of work, the replacement rate increases by 7.5 percentage points and 10 percentage points for Scenarios 2 and 3, respectively. However, in these two scenarios, the replacement rate remains at the level of $90 \%$ of net wage if the individual chooses to retire at age 68 . Scenarios 4 and 5 show the pension income incentive. While the two scenarios keep the increase in the replacement rate for each additional year of work at the level of 5 percentage points, they change the replacement rate at each year of retirement, regardless of age of retirement. In Scenario 4, the replacement rate is $85 \%$ for retiring at age 68, while in Scenario 5 it is $80 \%$ for retiring at that age.

Scenarios 6 to 10 introduce gradual retirement. In these scenarios, individual's work 50\% of the normal full-time work schedule in the Netherlands and are retired for the other $50 \%{ }^{12}$ The total net income received in gradual retirement is the sum of the part-time wage and the part-time pension and equals the pension after full-time retirement. Scenario 6 is the gradual retirement baseline scenario. It offers a replacement rate of $90 \%$ of the net wage if the individual chooses to work part-time at age 66, and fully retires at age 70. For each additional year of work, the replacement rate increases by 2.5 percentage points. This is half of what the individual would have built up by continuing working full-time for an additional year. This implies that in the case of the baseline scenario, a person who first retires part-time at age 69 and thereafter retires full-time at age 70 receives a replacement rate of only $97.5 \%$ at age 69 . The replacement rate at age 69 for a parttimer consists then of $50 \%$ wage and $47.5 \%$ pension income. Starting at age 70 , this person continues to receive a pension of $97.5 \%$ until death, implying less earnings than when he/she had chosen the full-retirement option at age 70 without any preceding part-time retirement (a replacement rate of $100 \%$ in the full-time scenario). In line with the actual pension system in the Netherlands, we thus incorporate both part-time and full-time retirement into our experiment in such a way that people do not automatically get full benefits.

\footnotetext{
9 To check the representativeness of our estimation sample, we use administrative data of the pension fund to compare basic characteristics of the employees in the population sample with those in the estimation sample. We find that there are no significant differences in age, wage, sector of occupation, and number of contractual work hours of employees between the two samples.

10 For gradual retirement in our scenarios, each additional year of gradual retirement is counted as half a year in terms of accrual rates.

11 Note that net replacement rates above $100 \%$ are realistic in the Netherlands. According to the OECD (2015), the average net replacement rate in the Netherlands in 2015 was on average $96.7 \%$ for all workers and $101.3 \%$ for workers with low income during their working life because of the first tier state pensions. In 2013, these percentages were even higher, with $101.1 \%$ on average for all workers and $104.8 \%$ for workers with low income. These high replacement rates are partly due to the fact that the retired pay lower income taxes than those employed.

12 This corresponds roughly with the average number of hours workers intend to retire part-time in the public sector in real life, as reported in the ROA Public Sector Survey (2014).
} 
Table 1

Replacement rates in the retirement scenarios.

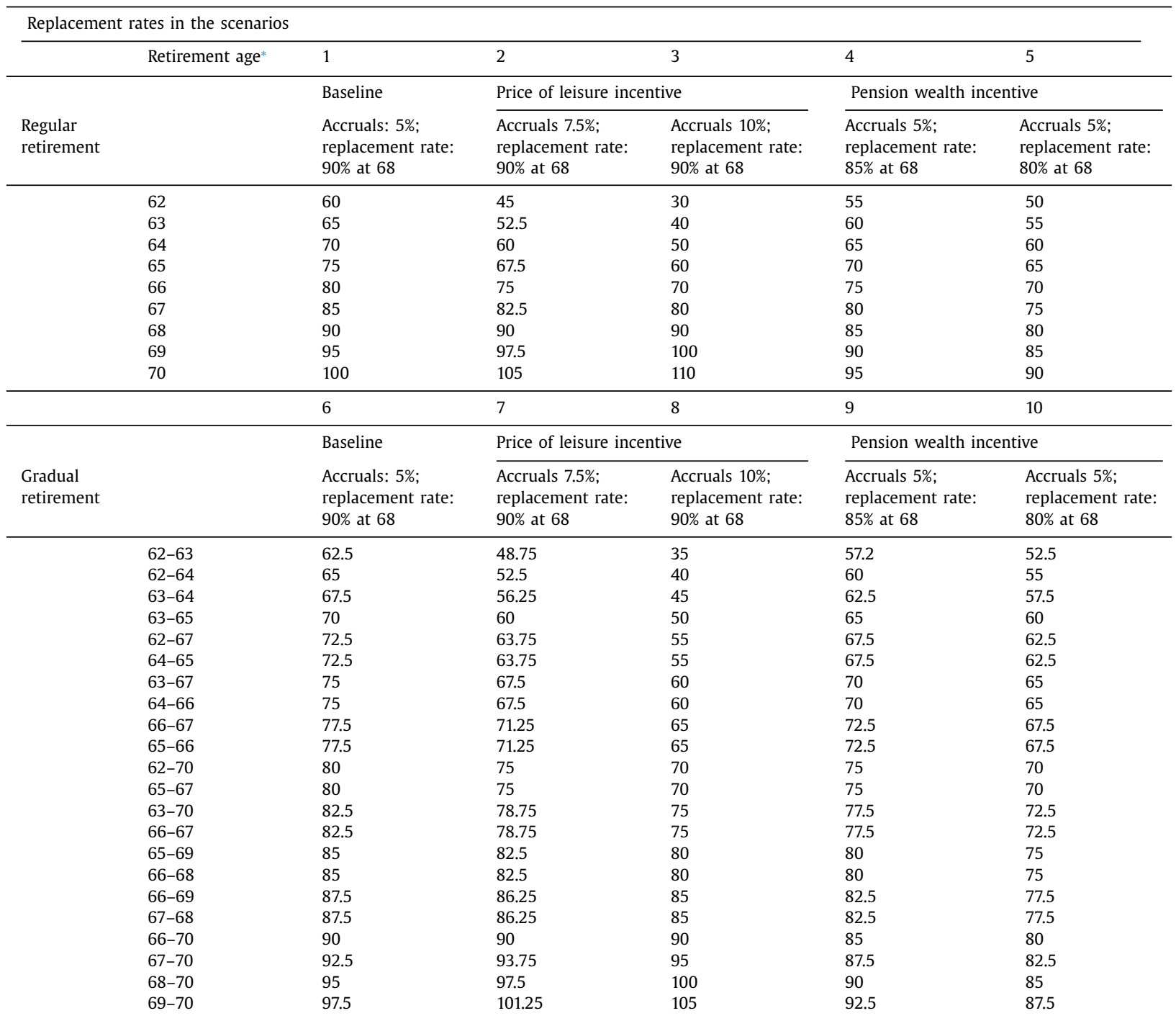

* Note: Under gradual retirement scenarios, the first age is the age of starting work on a part-time (gradual) basis, and the second age is the age of full retirement.

Scenarios 7 and 8 increase the price of leisure incentive. For each full-time-equivalent year of work, the replacement rate increases by 7.5 percentage points and 10 percentage points in Scenarios 7 and 8 , respectively ( 3.75 percentage points and 5 percentage points, for each additional year of gradual retirement, respectively). The replacement rate is $90 \%$ of the net wage if the individual chooses to work part-time at age 66, and fully retires at age 70. Scenarios 9 and 10 keep the increase in replacement rate for each additional year of full-time-equivalent work at the level of 5 percentage points, but decrease the replacement rate regardless of age of retirement. In Scenario 9, the replacement rate is $85 \%$ (80\% in Scenario 10 ) when an individual gradually retires at age 66 and fully retires at age 70 .

Finally, after the stated preferences experiment, respondents were asked to rank their choices on (part-time or full-time) retirement ages and replacement rates in the various scenarios from most preferred (coded 6) to least preferred (coded 1). ${ }^{13}$

${ }^{13}$ We do not find evidence that respondents had difficulties in making decisions in the different scenarios. Non-response on the vignettes was low: only 36 respondents did not make a decision. Moreover, respondents answered the survey question which asked them to rank their previous answers to the vignettes in a consistent way. Table 7 shows that they generally prefer the answer they gave in the vignette which contains the most generous retirement scheme. The main reason that most respondents seem to understand the vignettes is that we present retirement schemes in a similar way as actual retirement schemes are presented in brochures from the public sector pension fund, unions, and employers when pension reforms were enacted in the past decade. Much of the past communication involved presenting specific retirement ages in combination with accompanying pension replacement rates. Recent communication tools allow for more flexible ways of checking which pension income employees will receive when retiring at specific ages. 
Table 2

Background characteristics.

\begin{tabular}{lll}
\hline Characteristic & Average & Standard deviation \\
\hline Age & 56.12 & 5.70 \\
Gender (1 if male) & 0.62 & 0.48 \\
Married & 0.82 & 0.39 \\
High educated & 0.72 & 0.44 \\
Intermediate educated & 0.24 & 0.43 \\
Low educated & 0.04 & 0.20 \\
Log monthly wage & 7.73 & 0.54 \\
Full-time job & 0.79 & 0.41 \\
Partner with income & 0.71 & 0.45 \\
Partner with work & 0.57 & 0.50 \\
Self-assessed health (on a scale from 1 to 5) & 2.06 & 0.75 \\
Physically demanding jobs (on a scale from 0 to 10) & 2.02 & 2.17
\end{tabular}

\subsection{Descriptive statistics}

Table 2 shows summary statistics of respondents' main background characteristics. This table shows that the majority of respondents in our analysis are male, highly educated, full-time employees with an average age of 56. The proportion of highly educated public sector workers in our sample is consistent with that in other representative data sets, such as the Dutch Labour Supply Panel and the Dutch Labour Force Survey. To check the randomisation of the scenarios in the stated preferences experiment, we also separately analyse the summary statistics for all 10 retirement scenarios. We found no statistically significant differences in background characteristics across the scenarios (see Table A1 in the Appendix).

\subsection{Empirical approach}

The effect of gradual retirement on the total labour supply of our respondents is a net effect of the hours worked during gradual retirement, the age of gradual retirement, and the duration of gradual retirement. The main question is whether gradual retirement postpones full retirement enough to offset the negative effect on the number of hours worked of having an earlier start to the retirement process in the years of gradual retirement before full retirement. We estimate OLS models in which we regress the preferred age of full retirement, the first observed preferred retirement age (including full-time as well as part-time retirement) and the full-time-equivalent age of retirement (measuring total labour supply at the end of a worker's career) on the characteristics of the pension schemes in the stated preferences experiment. By so doing, we identify to what extent the postponement of full-time retirement due to the introduction of gradual retirement is cancelled out by a potential decrease in the date of the start of the retirement process and a reduction in working hours in the years preceding full retirement.

The characteristics of the pension schemes include a dummy variable indicating whether the scenario includes gradual retirement, the two variables indicating which financial incentives are given in the scenario, and which randomisation order of the scenarios is applied. Because each individual in the data set reported a retirement age under six different retirement scenarios, we use a clustered sandwich estimator to allow for intragroup correlation at the individual level (Rogers 1993; Wooldridge 2002).

The full-time retirement age measures when workers retire full-time, irrespective of whether workers had the opportunity to gradually retire before this age. The first observed preferred retirement age is a dummy measuring whether workers take up any form of retirement. When individuals retire full-time, this age is identical to the full-time retirement age; in case of part-time retirement, it will be lower than the full-time retirement age. This variable thus measures the number of months workers would move the start of the retirement process forward if they had the gradual retirement option. Finally, the full-time equivalent age of retirement takes into account the period in which workers were part-time retired until fulltime retirement and measures the net effect on labour supply. Because part-time retirement in our scenarios means that individuals work $50 \%$ of the time and are retired for the other $50 \%$, the full-time equivalent age of retirement increases by only 6 months with every additional year that individuals are part-time retired. In the case of a full-time pension scheme, an increase in the chosen age of retirement equals the increase in the full-time-equivalent age of retirement.

The main explanatory variable in the OLS estimations is a dummy variable, which takes the value 1 if the retirement scenario includes gradual retirement (Scenarios 6-9), and 0 otherwise. We further include two variables that measure the price of leisure and pension income incentives. We measure the price of leisure incentive by a variable that takes the value 0 for Scenarios 1, 4, 5, 6, 9, and 10 (5\% accruals), the value 1 for Scenarios 2 and 7 (7.5\% accruals), and the value 2 for Scenarios 3 and 8 (10\% accruals). Thus, a one-point increase on this scale represents the effect of a 2.5-percentage-point increase in the price of leisure. We measure the pension income incentive by a variable that takes the value 0 for Scenarios $1,2,3,6,7$, and 8 (90\% replacement rate), the value 1 for Scenarios 4 and 9 ( $85 \%$ replacement rate), and the value 2 for Scenarios 5 and 10 (80\% replacement rate). Therefore, a one-point increase on this scale represents a five-percentage-point 
Table 3

Retirement scenarios, retirement age, and full-time-equivalent age of retirement.

\begin{tabular}{|c|c|c|c|c|c|}
\hline Scenario & 1 & 2 & 3 & 4 & 5 \\
\hline \multirow[b]{2}{*}{ Regular retirement } & Baseline & \multicolumn{2}{|l|}{ Price of leisure incentive } & \multicolumn{2}{|l|}{ Pension wealth incentive } \\
\hline & $\begin{array}{l}\text { Accruals: } 5 \% \text {; } \\
\text { replacement rate: } 90 \% \\
\text { at } 68\end{array}$ & $\begin{array}{l}\text { Accruals } 7.5 \% \text {; } \\
\text { replacement rate: } 90 \% \\
\text { at } 68\end{array}$ & $\begin{array}{l}\text { Accruals } 10 \% \text {; } \\
\text { replacement rate: } 90 \% \\
\text { at } 68\end{array}$ & $\begin{array}{l}\text { Accruals } 5 \% \text {; } \\
\text { replacement rate: } 85 \% \\
\text { at } 68\end{array}$ & $\begin{array}{l}\text { Accruals } 5 \% \text {; } \\
\text { replacement rate: } 80 \% \\
\text { at } 68\end{array}$ \\
\hline Retirement age & $\begin{array}{l}64.97 \\
(1.80)\end{array}$ & $\begin{array}{l}65.84 \\
(1.56)\end{array}$ & $\begin{array}{l}66.05 \\
(1.36)\end{array}$ & $\begin{array}{l}65.40 \\
(1.72)\end{array}$ & $\begin{array}{l}65.99 \\
(1.77)\end{array}$ \\
\hline $\begin{array}{c}\text { Full-time-equivalent } \\
\text { age of retirement }\end{array}$ & $\begin{array}{l}64.97 \\
(1.80)\end{array}$ & $\begin{array}{l}65.84 \\
(1.56)\end{array}$ & $\begin{array}{l}66.05 \\
(1.36)\end{array}$ & $\begin{array}{l}65.40 \\
(1.72)\end{array}$ & $\begin{array}{l}65.99 \\
(1.77)\end{array}$ \\
\hline \multirow[t]{2}{*}{ Scenario } & 6 & 7 & 8 & 9 & 10 \\
\hline & Baseline & \multicolumn{2}{|l|}{ Price of leisure incentive } & \multicolumn{2}{|l|}{ Pension wealth incentive } \\
\hline Gradual retirement & $\begin{array}{l}\text { Accruals: } 5 \% \text {; } \\
\text { replacement rate: } 90 \% \\
\text { at } 68\end{array}$ & $\begin{array}{l}\text { Accruals } 7.5 \% \text {; } \\
\text { replacement rate: } 90 \% \\
\text { at } 68\end{array}$ & $\begin{array}{l}\text { Accruals } 10 \% \text {; } \\
\text { replacement rate: } 90 \% \\
\text { at } 68\end{array}$ & $\begin{array}{l}\text { Accruals } 5 \% \text {; } \\
\text { replacement rate: } 85 \% \\
\text { at } 68\end{array}$ & $\begin{array}{l}\text { Accruals } 5 \% \text {; } \\
\text { replacement rate: } 80 \% \\
\text { at } 68\end{array}$ \\
\hline Retirement age & $\begin{array}{l}65.95 \\
(1.83)\end{array}$ & $\begin{array}{l}66.65 \\
(1.76)\end{array}$ & $\begin{array}{l}67.18 \\
(1.73)\end{array}$ & $\begin{array}{l}66.34 \\
(1.75)\end{array}$ & $\begin{array}{l}66.88 \\
(1.92)\end{array}$ \\
\hline $\begin{array}{c}\text { Full-time-equivalent } \\
\text { age of retirement }\end{array}$ & $\begin{array}{l}64.77 \\
(1.47)\end{array}$ & $\begin{array}{l}65.36 \\
(1.38)\end{array}$ & $\begin{array}{l}65.79 \\
(1.27)\end{array}$ & $\begin{array}{l}65.10 \\
(1.44)\end{array}$ & $\begin{array}{l}65.59 \\
(1.56)\end{array}$ \\
\hline
\end{tabular}

Note: In the case of a full-time pension scheme, the increase in the preferred age of retirement is equal to the increase in the full-time-equivalent retirement age. Because employees who gradually retire are defined as working $50 \%$ of a full-time job in the vignettes, an increase in the preferred part-time retirement age by 1 year increases the full-time equivalent retirement age by only 6 months.

decrease in pension income. Further, we include dummy variables in our models to control for the randomisation order of the scenarios. ${ }^{14}$

Furthermore, we estimate a multinomial logit regression on the preferred full-time retirement age, which allows us to check for nonlinearities in the impact of gradual retirement on early and late full-time retirement. For our analyses on how respondents ranked their choices on (part-time or full-time) retirement ages and replacement rates in the various scenarios, we use a rank-ordered logit. The rank-ordered logit model is specifically designed to deal with ranked data in which decision makers combine attributes of alternatives into overall evaluations of the attractiveness of these alternatives. The ranked ordered logit model is a generalization of a version of McFadden's choice model without alternative-specific covariates. It explicitly takes into account that the rank of an individual choice depends on the ranking of the other choices.

\section{Gradual retirement, retirement age, and labour supply}

\subsection{Retirement choices}

Fig. 1 shows the distribution of full retirement choices across the retirement scenarios. The figure clearly shows that gradual retirement scenarios shift upwards the age at which workers fully retire. While the retirement age that is most often chosen in the full-time retirement scenarios ranges from 65 to 66, respondents most often choose age 67 for full retirement in gradual retirement scenarios. Age 65 corresponds to the former AOW eligibility age in the Netherlands, while ages 66 and 67 correspond to the higher eligibility ages as of 2018 and 2021, respectively. The figure further shows that the preferred full-time retirement age is responsive to financial incentives, and that at each level of financial incentive, the fulltime retirement age is slightly higher in gradual retirement scenarios than in full-time retirement scenarios. Most strikingly, the gradual retirement option in combination with strong financial incentives to postpone retirement induces $17.5 \%$ of our sample to continue working until age 70 .

Table 3 summarises average full-time retirement age and full-time-equivalent age of retirement under each retirement scenario. This table shows that under the full-time retirement scenarios, the average retirement age (and full-time-equivalent age of retirement) in the baseline scenario is 64.97 years. The average retirement age increases to 65.84 when the price of leisure incentive increases from 5 percentage points to 7.5 percentage points (Scenario 2 ), and additionally slightly increases to 66.05 when the price of leisure incentive goes from 7.5 percentage points to 10 percentage points (Scenario 3 ). A 5percentage-point decrease in pension income (Scenario 4) increases the age of retirement to 65.40. A further decrease in pension income by 5 percentage points increases the average age of retirement to almost 66 years (Scenario 5 ).

This table further confirms that average full-time expected retirement ages are higher under gradual retirement scenarios than under full-time retirement scenarios with the same price of leisure or pension income incentives. However, the results change considerably when we examine the average full-time-equivalent retirement age. In the baseline scenario for gradual

\footnotetext{
14 These dummies are never statistically significant.
} 

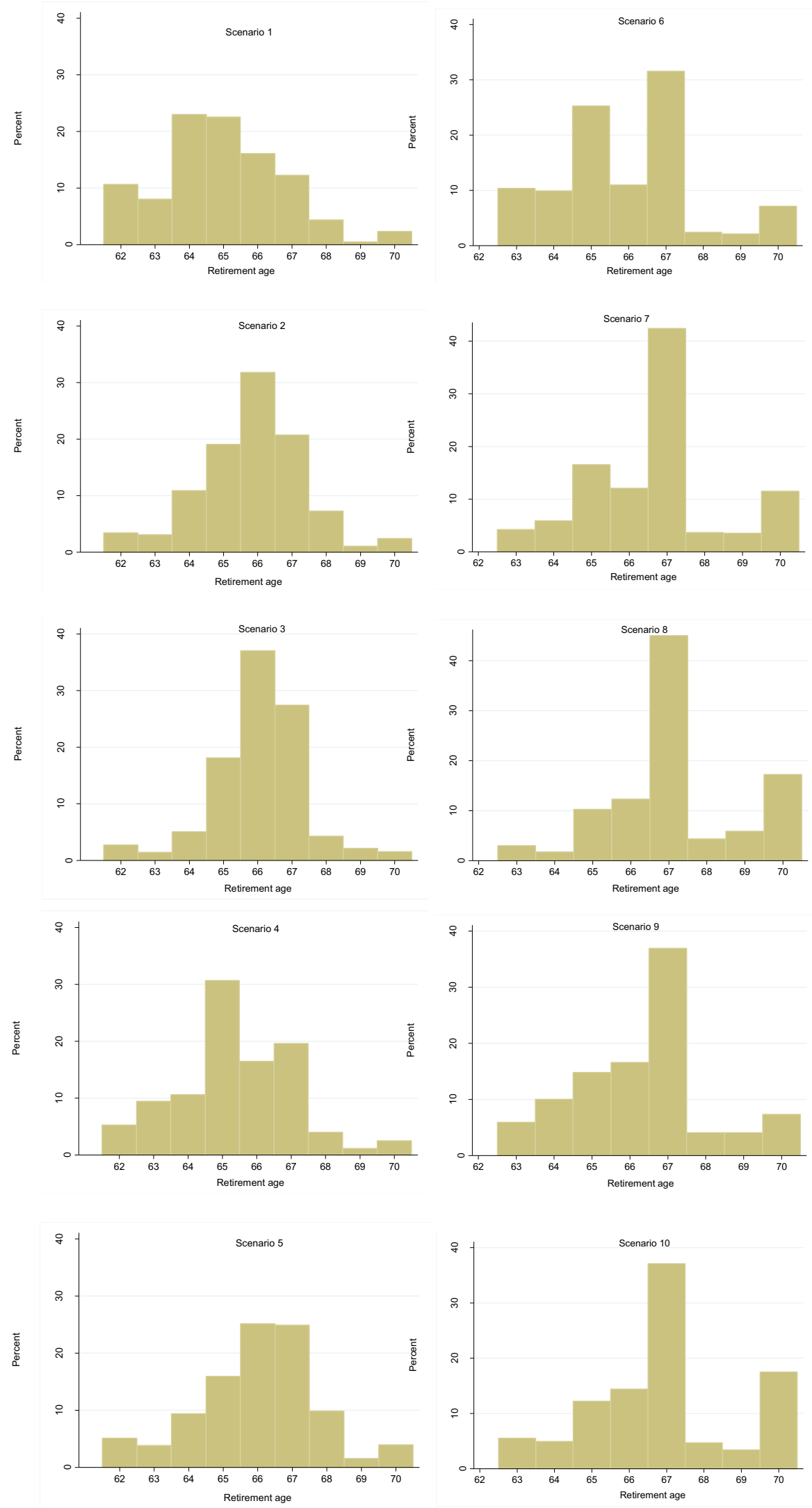

Fig. 1. Distribution of chosen full-retirement ages. 
Table 4

Retirement scenarios and duration of part-time retirement.

\begin{tabular}{lll}
\hline Duration of part-time retirement & Average & Standard deviation \\
\hline Scenario 6 Base scenario: accruals: 5\%; replacement rate: $90 \%$ at 68 & 2.37 & 1.51 \\
Scenario 7 Price of leisure incentive: accruals 7.5\%; replacement rate: $90 \%$ at 68 & 2.57 & 1.76 \\
Scenario 8 Price of leisure incentive: accruals 10\%; replacement rate: 90\% at 68 & 2.77 & 2.09 \\
Scenario 9 Pension wealth incentive: accruals 5\%; replacement rate: 85\% at 68 & 2.46 & 1.50 \\
Scenario 10 Pension wealth incentive: accruals 5\%; replacement rate: 80\% at 68 & 2.58 & 1.85 \\
\hline
\end{tabular}

Table 5

Relationship between gradual retirement, full-time retirement age, first observed and full-time-equivalent age of retirement.

\begin{tabular}{|c|c|c|c|c|c|c|c|c|c|}
\hline \multirow[b]{2}{*}{ VARIABLES } & $(1)$ & $(2)$ & (3) & $(4)$ & (5) & $(6)$ & $(7)$ & $(8)$ & (9) \\
\hline & \multicolumn{3}{|c|}{ Full-time retirement age } & \multicolumn{3}{|c|}{$\begin{array}{l}\text { First observed retirement age } \\
\text { (full-time or part-time) }\end{array}$} & \multicolumn{3}{|c|}{ Full-time-equivalent age of retirement } \\
\hline Gradual retirement & $\begin{array}{l}0.977^{* * *} \\
(0.024)\end{array}$ & $\begin{array}{l}0.976^{* * *} \\
(0.024)\end{array}$ & $\begin{array}{l}0.964^{* * *} \\
(0.029)\end{array}$ & $\begin{array}{l}-1.551^{* * *} \\
(0.023)\end{array}$ & $\begin{array}{l}-1.552^{* * * *} \\
(0.023)\end{array}$ & $\begin{array}{l}-1.411^{* * *} \\
(0.029)\end{array}$ & $\begin{array}{l}-0.287^{* * *} \\
(0.017)\end{array}$ & $\begin{array}{l}-0.288^{* * *} \\
(0.017)\end{array}$ & $\begin{array}{l}-0.224^{* * *} \\
(0.023)\end{array}$ \\
\hline Price of leisure incentive & & $\begin{array}{l}0.601^{* * *} \\
(0.017)\end{array}$ & $\begin{array}{l}0.591^{* * *} \\
(0.017)\end{array}$ & & $\begin{array}{l}0.490^{* * *} \\
(0.014)\end{array}$ & $\begin{array}{l}0.580^{* * *} \\
(0.017)\end{array}$ & & $\begin{array}{l}0.545^{* * *} \\
(0.013)\end{array}$ & $\begin{array}{l}0.585^{* * *} \\
(0.016)\end{array}$ \\
\hline $\begin{array}{l}\text { Gradual retirement* Price of } \\
\text { leisure incentive }\end{array}$ & & & $\begin{array}{l}0.021 \\
(0.026)\end{array}$ & & & $\begin{array}{l}-0.180^{* * *} \\
(0.023)\end{array}$ & & & $\begin{array}{l}-0.079^{* * *} \\
(0.017)\end{array}$ \\
\hline Pension income incentive & & $\begin{array}{l}0.464^{* * *} \\
(0.015)\end{array}$ & $\begin{array}{l}0.462^{* * *} \\
(0.015)\end{array}$ & & $\begin{array}{l}0.424^{* * *} \\
(0.013)\end{array}$ & $\begin{array}{l}0.472^{* * *} \\
(0.016)\end{array}$ & & $\begin{array}{l}0.444^{* * * *} \\
(0.012)\end{array}$ & $\begin{array}{l}0.467^{* * *} \\
(0.015)\end{array}$ \\
\hline $\begin{array}{l}\text { Gradual retirement*Pension } \\
\text { income incentive }\end{array}$ & & & $\begin{array}{l}0.004 \\
(0.024)\end{array}$ & & & $\begin{array}{l}-0.097^{* * *} \\
(0.022)\end{array}$ & & & $\begin{array}{l}-0.047^{* * *} \\
(0.017)\end{array}$ \\
\hline Constant & $\begin{array}{l}65.695^{* * *} \\
(0.097)\end{array}$ & $\begin{array}{l}65.094^{* * *} \\
(0.101)\end{array}$ & $\begin{array}{l}65.101^{* * * *} \\
(0.101)\end{array}$ & $\begin{array}{l}65.690^{* * *} \\
(0.092)\end{array}$ & $\begin{array}{l}65.200^{* * * *} \\
(0.094)\end{array}$ & $\begin{array}{l}65.129^{* * *} \\
(0.095)\end{array}$ & $\begin{array}{l}65.692^{* * *} \\
(0.092)\end{array}$ & $\begin{array}{l}65.147^{* * * *} \\
(0.095)\end{array}$ & $\begin{array}{l}65.115^{* * *} \\
(0.096)\end{array}$ \\
\hline Observations & 10,560 & 10,560 & 10,560 & 10,560 & 10,560 & 10,560 & 10,560 & 10,560 & 10,560 \\
\hline R-squared & 0.072 & 0.128 & 0.128 & 0.191 & 0.233 & 0.234 & 0.016 & 0.079 & 0.080 \\
\hline
\end{tabular}

Note: Full-time-equivalent age of retirement is estimated to be six months for each additional year of (part-time) employment/retirement. Dummies for randomisation of scenarios included as controls. OLS estimates including robust standard errors corrected for clustering on the individual level are in parentheses. ${ }^{* * *} p<.01,{ }^{* *} p<.05,{ }^{*} p<.1$.

retirement (Scenario 6), the average retirement age is 65.95, which is almost 1 year later than in the full-time baseline scenario (Scenario 1). The average full-time-equivalent retirement age is, however, only 64.77, which is less than the average full-time retirement age in baseline Scenario 1. When the price of leisure incentive increases to $7.5 \%$ and $10 \%$ in the gradual retirement scenarios (Scenarios 7 and 8), average retirement age increases to 66.65 and 67.18, respectively. The corresponding average full-time-equivalent retirement age increases only to 65.36 and 65.79 , respectively. This implies that the average full-time-equivalent retirement age in these two scenarios is lower than the average full-time-equivalent retirement age in full-time retirement Scenarios 2 and 3. Similarly, decreasing pension income to 85\% and 80\% in gradual retirement Scenarios 9 and 10 increases average retirement age to 66.34 and 66.68, and increases average full-time-equivalent retirement age to 65.10 and 65.59, respectively. The average full-time-equivalent age in these two scenarios is again lower than in Scenarios 4 and 5. The results presented in Table 3 therefore suggest that, although gradual retirement increases the retirement age, its impact on workers' labour supply is negative. Moreover, the table shows that financial incentives to postpone retirement, irrespective of whether they generate price of leisure or income shocks, increase both the expected retirement age and labour supply.

Fig. 2 sheds more light on the distribution of the duration of the period in which workers are part-time retired. For the baseline gradual retirement scenario, we observe that most workers choose a relatively short duration of part-time retirement: $73.6 \%$ of respondents choose to work only 1 or 2 years part-time before they fully retire. This short duration suggests that most workers consider part-time retirement as a sort of short-term bridge job between full-time employment and full-time retirement, allowing them to gradually withdraw from the labour market. The figure also shows a small peak in the distribution at the part-time retirement duration of 4 years and further indicates that only a small minority of workers (8.9\%) wishes to retire part-time for more than 5 years. Further, it is clear that introduction of financial incentives to continue working slightly increases the duration of the period in which workers are part-time retired. This is confirmed by Table 4, which presents the average part-time retirement duration for each scenario. Duration of part-time retirement increases from 2 years and 4 months in the baseline scenario to 2 years and 9 months in the scenario in which the price of leisure incentive increases to $10 \%$ (Scenario 8). A drop in pension income of $10 \%$ leads to a duration of part-time retirement of 2 years and 7 months.

\subsection{Main regression analysis}

Table 5 shows OLS estimations of the effect of gradual retirement on expected full-time retirement age (Columns 1-3), first observed retirement age (Columns 4-6), and full-time-equivalent retirement age (Columns 7-9). Columns 1, 4, and 

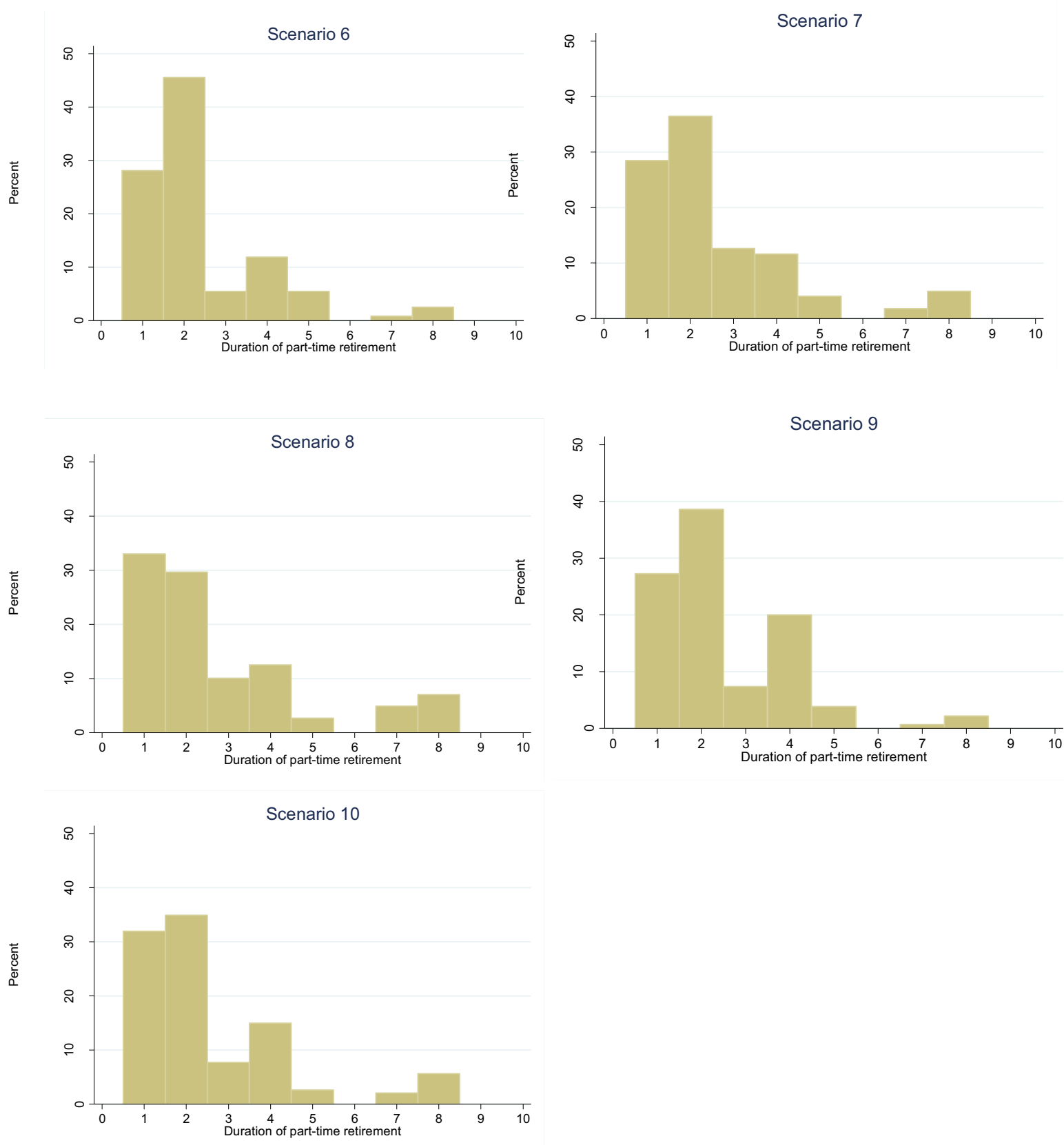

Fig. 2. Distribution of chosen duration of part-time retirement.

7 show raw estimates that include only a dummy variable indicating whether the scenario includes gradual retirement. Columns 2, 5, and 8 control for financial incentives (i.e., price of leisure and pension income), and Columns 3, 6, and 9 include an interaction between gradual retirement and financial incentives, to investigate the extent to which the impact of gradual retirement schemes differs given the financial incentives provided by the pension system to continue working. The table shows that in gradual retirement systems, workers expect to fully retire about one year (11.7 months) later than in full-time retirement systems.

In the part-time scenarios, the first observed retirement age is, however, on average 18.6 months earlier than in the fulltime scenarios. Gradual retirement thus postpones the date of complete retirement, but substantially brings forward the age at which the retirement process starts by entering gradual retirement. When we consider the full-time equivalent retirement age, we observe that in the gradual retirement scenarios workers' labour supply is, on average, 3.4 months lower. The replacement of full-time retirement schemes with gradual retirement schemes will therefore have negative consequences on 


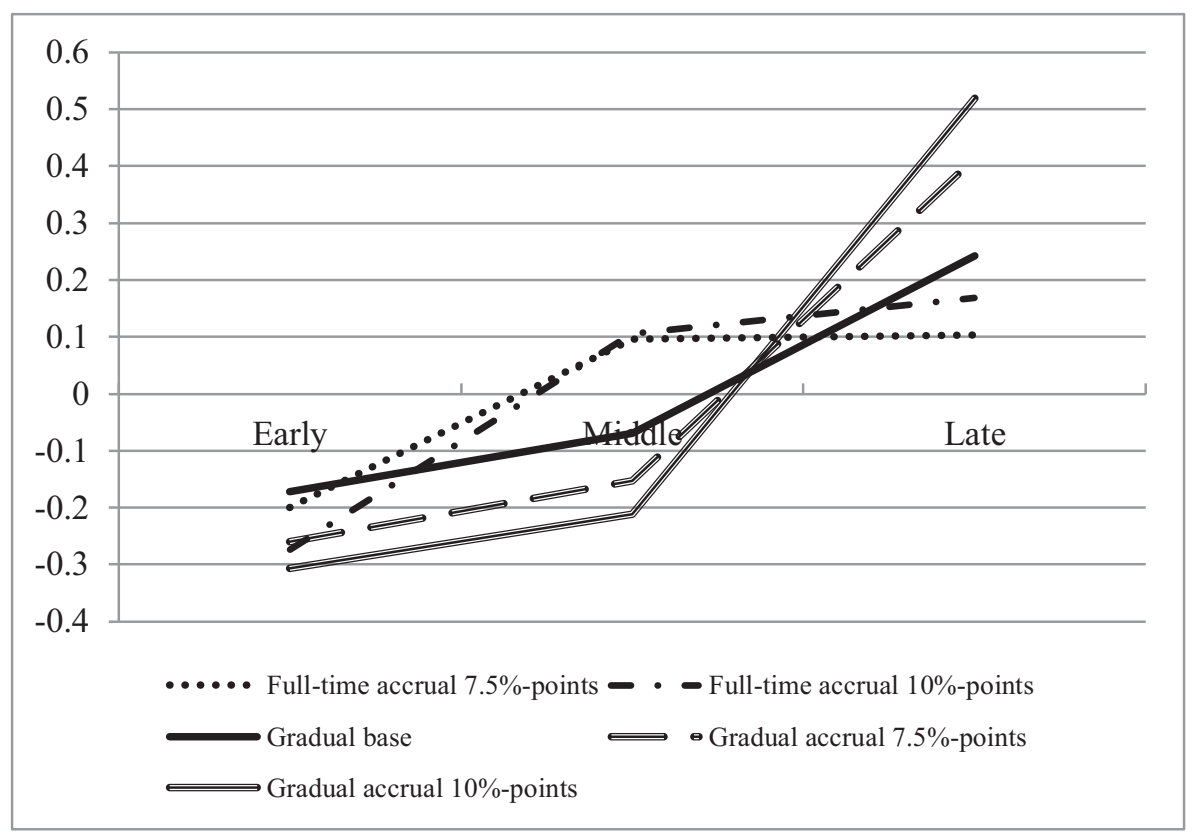

Fig. 3. (a): Differences in marginal effects of a multinomial logit on early, middle, and late retirement: shocks in accrual rates and gradual retirement (marginal effects relative to full-time base scenario). (b): Differences in marginal effects of a multinomial logit on early, middle, and late retirement: income shocks and gradual retirement (marginal effects relative to full-time base scenario).

workers' lifetime labour supply. This is because the positive effect of gradual retirement on labour supply in terms of number of years in paid employment, as a consequence of the postponement of full-time retirement (an increase in labour supply of 11.7 months $x 0.5=5.9$ months), is outweighed by the reduction in labour supply because of the drop in weekly working hours due to the earlier start of the (gradual) retirement process: a decrease of 18.6 months $x 0.5=-9.3$ months. Adding these different impacts on workers' labour supply yields a total drop in labour supply of 3.4 months. Gradual retirement has thus an asymmetric effect on the timing of various retirement stages by inducing an earlier start to the retirement process and not postponing full-time retirement enough to generate an offsetting effect on hours worked.

Table 5 further shows that a 2.5-percentage-point increase in accruals induces workers to postpone retirement by 7.2 months, and that a 5-percentage-point decrease in pension income increases the retirement age by 5.6 months. More importantly, we find no significant interaction effect between the financial incentives and the part-time retirement indicator on expected full-time retirement age. We do find, however, a small statistically significant negative interaction effect on the full-time-equivalent age of retirement, suggesting that labour supply under gradual retirement scenarios is slightly less responsive to changes in financial incentives. ${ }^{15}$

Fig. 3(a) and (b) show the marginal effects (relative to the full-retirement base Scenario 1) for each retirement scenario on the probability of fully retiring at age 67 or older, at ages 65 and 66, or earlier (at ages 62-64). The marginal effects are calculated based on the coefficient estimates of a multinomial logit model (see Table A3 in the Appendix for the coefficient estimates) that allows us to check for nonlinearities in the impact of gradual retirement on full-time retirement expectations. ${ }^{16}$ The figures show results that are largely consistent with the OLS estimates in Table 5. Gradual retirement substantially reduces the likelihood that workers wish to retire early (17 percentage points less likely to retire than in the base scenario) or at ages 65 and 66 ( 7 percentage points less likely to retire). ${ }^{17}$ The figures further show that especially strong accrual rates in combination with gradual retirement are more likely to stimulate workers to retire late (at age 67 or later) compared to the base scenario. However, both interaction effects between the financial incentives and our gradual retirement indicator on the average expected full-time retirement age in Table 5 are not statistically significant. This means that introduction of gradual retirement stimulates later full-time retirement, irrespective of the financial incentive structure.

\footnotetext{
${ }^{15}$ Approximately $80 \%$ of all workers in our estimation sample work full time, and about $20 \%$ work part-time. Because the stated preferences experiment presents a hypothetical situation in which workers work part-time, we checked to what extent workers with part-time and full-time jobs respond differently to the vignettes. Table A4 in Appendix A shows that our main results are robust to the part-time status of the respondents in our estimation sample.

16 See also Van Soest et al. (2007) and Kantarci and Van Soest (2013).

17 This result is robust to different definitions of early and late retirement.
} 


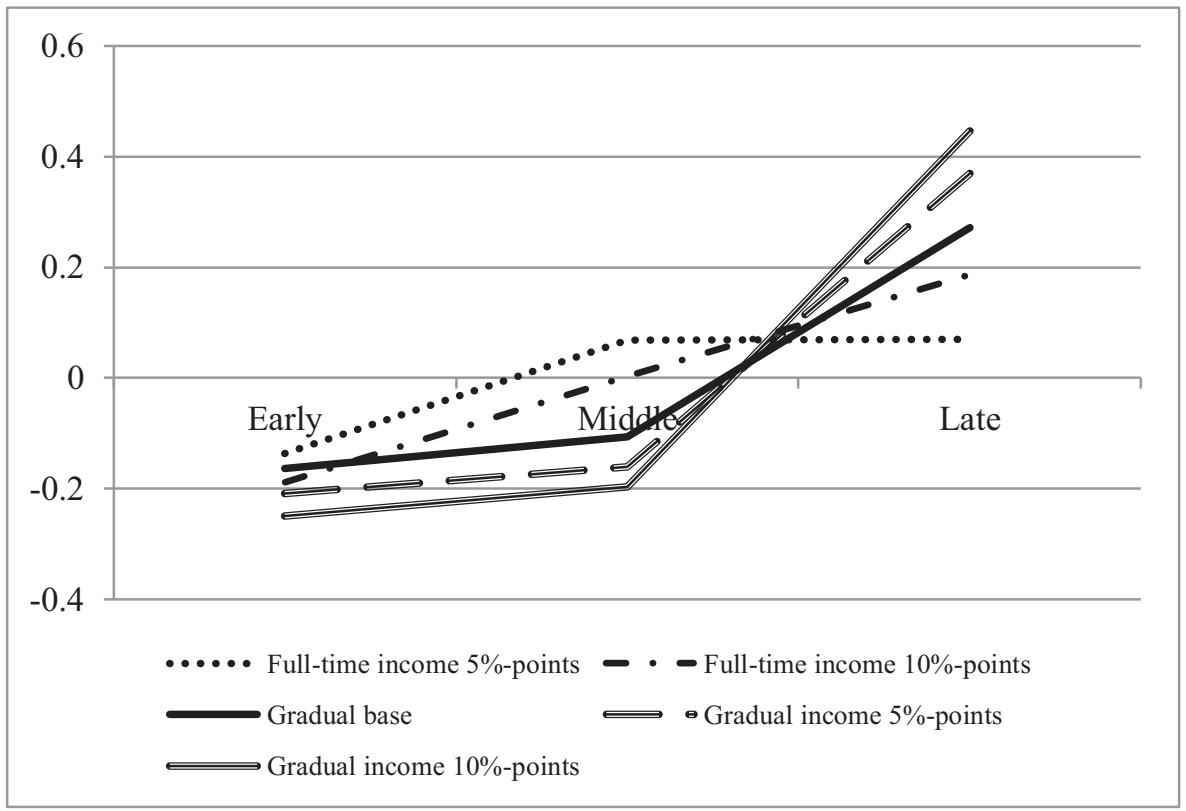

Fig. 3. Continued

Table 6

Testing for nonlinear effects of financial incentives.

\begin{tabular}{|c|c|c|c|}
\hline VARIABLES & $\begin{array}{l}\text { (1) } \\
\text { Full-time retirement } \\
\text { age }\end{array}$ & $\begin{array}{l}\text { (2) } \\
\text { First observed retirement age } \\
\text { (full-time or part-time) }\end{array}$ & $\begin{array}{l}\text { (3) } \\
\text { Full-time-equivalent } \\
\text { age of retirement }\end{array}$ \\
\hline Gradual retirement & $\begin{array}{l}0.986^{* * *} \\
(0.030)\end{array}$ & $\begin{array}{l}-1.388^{* * *} \\
(0.029)\end{array}$ & $\begin{array}{l}-0.201^{* * *} \\
(0.024)\end{array}$ \\
\hline $\begin{array}{l}\text { Regular retirement: Price of leisure incentive } 7.5 \% \text { (baseline } \\
\text { regular retirement scenario= ref.) }\end{array}$ & $\begin{array}{l}0.841^{* * *} \\
(0.028)\end{array}$ & $\begin{array}{l}0.788^{* * *} \\
(0.028)\end{array}$ & $\begin{array}{l}0.815^{* * *} \\
(0.027)\end{array}$ \\
\hline Regular retirement: Price of leisure incentive $10 \%$ & $\begin{array}{l}1.119 * * * \\
(0.035)\end{array}$ & $\begin{array}{l}1.113^{* * *} \\
(0.034)\end{array}$ & $\begin{array}{l}1.116 * * * \\
(0.033)\end{array}$ \\
\hline Regular retirement: Pension wealth incentive 5\% & $\begin{array}{l}0.420^{* * *} \\
(0.026)\end{array}$ & $\begin{array}{l}0.469^{* * *} \\
(0.026)\end{array}$ & $\begin{array}{l}0.444^{* * *} \\
(0.025)\end{array}$ \\
\hline Regular retirement: Pension wealth incentive $10 \%$ & $\begin{array}{l}0.986 * * * \\
(0.031)\end{array}$ & $\begin{array}{l}0.992^{* * *} \\
(0.032)\end{array}$ & $\begin{array}{l}0.989^{* * *} \\
(0.030)\end{array}$ \\
\hline $\begin{array}{l}\text { Gradual retirement: Price of leisure incentive } 7.5 \% \text { (baseline } \\
\text { gradual retirement scenario = ref.) }\end{array}$ & $\begin{array}{l}0.713^{* * *} \\
(0.042)\end{array}$ & $\begin{array}{l}0.460^{* * *} \\
(0.034)\end{array}$ & $\begin{array}{l}0.587^{* * *} \\
(0.025)\end{array}$ \\
\hline Gradual retirement: Price of leisure incentive $10 \% \%$ & $\begin{array}{l}1.207^{* * *} \\
(0.051)\end{array}$ & $\begin{array}{l}0.797^{* * *} \\
(0.040)\end{array}$ & $\begin{array}{l}1.002^{* * *} \\
(0.029)\end{array}$ \\
\hline Gradual retirement: Pension wealth incentive 5\% & $\begin{array}{l}0.428^{* * *} \\
(0.037)\end{array}$ & $\begin{array}{l}0.372^{* * *} \\
(0.030)\end{array}$ & $\begin{array}{l}0.400^{* * *} \\
(0.023)\end{array}$ \\
\hline Gradual retirement: Pension wealth incentive $10 \%$ & $\begin{array}{l}0.948^{* * *} \\
(0.047)\end{array}$ & $\begin{array}{l}0.754^{* * *} \\
(0.037)\end{array}$ & $\begin{array}{l}0.851^{* * *} \\
(0.028)\end{array}$ \\
\hline Constant & $\begin{array}{l}65.044^{* * *} \\
(0.101)\end{array}$ & $\begin{array}{l}65.081^{* * *} \\
(0.096)\end{array}$ & $\begin{array}{l}65.063^{* * *} \\
(0.096)\end{array}$ \\
\hline Observations & 10,560 & 10,560 & 10,560 \\
\hline R-squared & 0.129 & 0.235 & 0.081 \\
\hline
\end{tabular}

Note: Full-time-equivalent age of retirement is estimated to be six months for each additional year of (part-time) employment/retirement. Dummies for randomisation of scenarios included as controls. OLS estimates including robust standard errors corrected for clustering on the individual level are in parentheses. ${ }^{* * *} p<.01,{ }^{* *} p<.05,{ }^{*} p<.1$.

Apart from the nonlinearities in the impact of gradual retirement on retirement expectations, we should also examine in more detail whether there are nonlinear effects from the financial incentives provided by each scenario. ${ }^{18}$ Table 6 tests for nonlinear effects of each financial incentive in the scenarios by replacing the categorical variables with dummy variables indicating the scenario the respondents considered. The results show that the effects of the pension income incentives in the vignettes are indeed linearly associated with full-time retirement age. This is not entirely the case for the price of leisure

\footnotetext{
${ }^{18}$ Until now, we have used categorical variables for the price of leisure and pension income incentives in our regressions.
} 
Table 7

Ranking of preferences for different retirement scenarios.

\begin{tabular}{|c|c|c|}
\hline $\begin{array}{l}\text { Retirement scenario } \\
\text { Full-time schemes }\end{array}$ & Average ranking & Percentage most preferred scenario \\
\hline Scenario 1 Base scenario: accruals: $5 \%$; replacement rate: $90 \%$ at 68 & 5.13 & 57.4 \\
\hline Scenario 2 Price of leisure incentive: accruals $7.5 \%$; replacement rate: $90 \%$ at 68 & 3.83 & 5.0 \\
\hline Scenario 3 Price of leisure incentive: accruals 10\%; replacement rate: $90 \%$ at 68 & 2.85 & 2.2 \\
\hline Scenario 4 Pension wealth incentive: accruals 5\%; replacement rate: $85 \%$ at 68 & 3.80 & 2.4 \\
\hline Scenario 5 Pension wealth incentive: accruals 5\%; replacement rate: $80 \%$ at 68 & 2.54 & 0.9 \\
\hline \multicolumn{3}{|l|}{ Gradual schemes } \\
\hline Scenario 6 Base scenario: accruals: 5\%; replacement rate: $90 \%$ at 68 & 4.39 & 26.2 \\
\hline Scenario 7 Price of leisure incentive: accruals $7.5 \%$; replacement rate: $90 \%$ at 68 & 3.06 & 2.6 \\
\hline Scenario 8 Price of leisure incentive: accruals 10\%; replacement rate: $90 \%$ at 68 & 1.95 & 1.0 \\
\hline Scenario 9 Pension wealth incentive: accruals 5\%; replacement rate: $85 \%$ at 68 & 3.06 & 1.3 \\
\hline Scenario 10 Pension wealth incentive: accruals 5\%; replacement rate: $80 \%$ at 68 & 1.85 & 1.1 \\
\hline
\end{tabular}

Note: In total, six scenarios were ranked by respondents. The most preferred scenario is attributed value 6 , while the least preferred scenario is attributed value 1 . Column 1 shows average ranking of the scenarios. Column 2 shows how many workers chose each scenario as their most preferred scenario.

Table 8

Ranking scenarios.

\begin{tabular}{|c|c|c|c|c|c|c|}
\hline & \multicolumn{3}{|l|}{ OLS } & \multicolumn{3}{|c|}{ Rank-ordered logit } \\
\hline & $(1)$ & (2) & (3) & $(4)$ & (5) & (6) \\
\hline Gradual retirement & $\begin{array}{l}-0.764^{* * *} \\
(0.044)\end{array}$ & $\begin{array}{l}-0.764^{* * *} \\
(0.043)\end{array}$ & $\begin{array}{l}-0.732^{* * *} \\
(0.054)\end{array}$ & $\begin{array}{l}-0.528^{* * *} \\
(0.027)\end{array}$ & $\begin{array}{l}-0.729 * * * \\
(0.029)\end{array}$ & $\begin{array}{l}-0.728^{* * *} \\
(0.044)\end{array}$ \\
\hline Price of leisure incentive & & $\begin{array}{l}-1.189^{* * *} \\
(0.024)\end{array}$ & $\begin{array}{l}-1.150^{* * *} \\
(0.031)\end{array}$ & & $\begin{array}{l}-0.953^{* * *} \\
(0.024)\end{array}$ & $\begin{array}{l}-0.949^{* * *} \\
(0.031)\end{array}$ \\
\hline $\begin{array}{l}\text { Gradual retirement* Price of leisure } \\
\text { incentive }\end{array}$ & & & $\begin{array}{l}-0.077^{* *} \\
(0.037)\end{array}$ & & & $\begin{array}{l}-0.010 \\
(0.040)\end{array}$ \\
\hline Pension income incentive & & $\begin{array}{l}-1.273^{* * *} \\
(0.021)\end{array}$ & $\begin{array}{l}-1.280^{* * *} \\
(0.028)\end{array}$ & & $\begin{array}{l}-1.056^{* * *} \\
(0.025)\end{array}$ & $\begin{array}{l}-1.060^{* * *} \\
(0.031)\end{array}$ \\
\hline $\begin{array}{l}\text { Gradual retirement*Pension income } \\
\text { incentive }\end{array}$ & & & $\begin{array}{l}0.015 \\
(0.038)\end{array}$ & & & $\begin{array}{l}0.009 \\
(0.041)\end{array}$ \\
\hline Constant & $\begin{array}{l}3.881^{* * *} \\
(0.022)\end{array}$ & $\begin{array}{l}5.112^{* * *} \\
(0.028)\end{array}$ & $\begin{array}{l}5.096 * * * \\
(0.033)\end{array}$ & & & \\
\hline Observations & 8897 & 8897 & 8897 & 8897 & 8897 & 8897 \\
\hline R-squared & 0.050 & 0.397 & 0.397 & & & \\
\hline
\end{tabular}

Note: In total, six scenarios were ranked by respondents. The most preferred scenario is attributed value 6 , while the least preferred scenario is attributed value 1. Columns 1-3 show OLS estimates and Columns 4-6 show rank-ordered logit estimates. The estimates include robust standard errors corrected for clustering on the individual level, which are in parentheses. ${ }^{* * *} p<.01,{ }^{* *} p<.05,{ }^{*} p<.1$.

incentives in the full-time retirement scenarios, where we observe a concave relationship. We do, however, find evidence for a linear relation for both pension income and the price of leisure incentives in the gradual retirement scenarios.

\subsection{Ranking preferences for gradual and full-time retirement}

From a theoretical perspective, we would expect that gradual retirement schemes contribute to improving lifetime utility, since they introduce the possibility of avoiding the shock of abrupt transition from full-time work to full-time retirement. Gradual retirement may further reduce the burden of work, and thereby reduce work-related stress and increase employee morale until full retirement (Reday-Mulvey and Delsen 1996; Reday-Mulvey 2000).

To measure respondents' preferences for gradual retirement over full retirement schemes, we asked respondents to rank the choices they made in each of the six vignettes. The respondents could rank their choices from most preferred (coded 6) to least preferred (coded 1). Column 1 of Table 7 shows the average ranking of each retirement scenario. This table shows that the baseline full-time retirement scenario, which also includes the most generous financial incentives, is most preferred (average rank: 5.13), while the baseline gradual retirement scenario is less often preferred (average rank: 4.39). Comparing the ranking of the other scenarios makes clear that none of the gradual retirement scenarios is, on average, preferred to the full-time scenarios with equivalent financial incentives. Column 2 of Table 7 further shows that $57 \%$ of all workers chose the baseline full-time retirement scenario as their most preferred scenario, while only $26 \%$ chose the baseline gradual retirement scenario as their most preferred scenario.

Table 8 reports OLS and rank-ordered logit estimates on how the various attributes of the retirement scenarios relate to the rank-order that respondents give to the scenarios. The rank-ordered logit takes into account that the rank of an individual choice is interdependent on the ranking of the other choices. Table 8 confirms that workers prefer full-time retirement irrespective of whether OLS or a rank-ordered logit is used. Scenarios with higher prices for leisure or stronger 
Table 9

Gradual retirement and full-time-equivalent age of retirement: the role of age.

\begin{tabular}{|c|c|c|c|c|c|c|c|c|c|}
\hline \multirow[b]{3}{*}{ VARIABLES } & (1) & $(2)$ & (3) & $(4)$ & $(5)$ & $(6)$ & $(7)$ & $(8)$ & (9) \\
\hline & \multicolumn{3}{|c|}{ Full-time retirement age } & \multicolumn{3}{|c|}{$\begin{array}{l}\text { First observed retirement age } \\
\text { (full-time or part-time) }\end{array}$} & \multicolumn{3}{|c|}{ Full-time-equivalent age of retirement } \\
\hline & Age $<=55$ & $\begin{array}{l}\text { Age }>55 \& \\
\text { Age }<60\end{array}$ & Age $>=60$ & Age $<=55$ & $\begin{array}{l}\text { Age }>55 \& \\
\text { Age }<60\end{array}$ & Age $>=60$ & Age $<=55$ & $\begin{array}{l}\text { Age }>55 \& \\
\text { Age }<60\end{array}$ & Age $>=60$ \\
\hline Gradual retirement & $\begin{array}{l}1.011^{* * *} \\
(0.052)\end{array}$ & $\begin{array}{l}0.967^{* * *} \\
(0.042)\end{array}$ & $\begin{array}{l}0.876^{* * *} \\
(0.066)\end{array}$ & $\begin{array}{l}-1.460^{* * *} \\
(0.055)\end{array}$ & $\begin{array}{l}-1.371^{* * *} \\
(0.041)\end{array}$ & $\begin{array}{l}-1.421^{* * *} \\
(0.058)\end{array}$ & $\begin{array}{l}-0.224^{* * *} \\
(0.044)\end{array}$ & $\begin{array}{l}-0.202^{* * *} \\
(0.032)\end{array}$ & $\begin{array}{l}-0.273^{* * *} \\
(0.049)\end{array}$ \\
\hline Price of leisure incentive & $\begin{array}{l}0.644^{* * *} \\
(0.033)\end{array}$ & $\begin{array}{l}0.598^{* * *} \\
(0.024)\end{array}$ & $\begin{array}{l}0.484^{* * *} \\
(0.034)\end{array}$ & $\begin{array}{l}0.634^{* * *} \\
(0.033)\end{array}$ & $\begin{array}{l}0.586^{* * *} \\
(0.023)\end{array}$ & $\begin{array}{l}0.478^{* * *} \\
(0.032)\end{array}$ & $\begin{array}{l}0.639^{* * *} \\
(0.032)\end{array}$ & $\begin{array}{l}0.592^{* * *} \\
(0.023)\end{array}$ & $\begin{array}{l}0.481^{* * *} \\
(0.032)\end{array}$ \\
\hline $\begin{array}{l}\text { Gradual retirement* Price of } \\
\text { leisure incentive }\end{array}$ & $\begin{array}{l}-0.027 \\
(0.045)\end{array}$ & $\begin{array}{l}0.022 \\
(0.037)\end{array}$ & $\begin{array}{l}0.101^{*} \\
(0.057)\end{array}$ & $\begin{array}{l}-0.178^{* * *} \\
(0.042)\end{array}$ & $\begin{array}{l}-0.208^{* * *} \\
(0.032)\end{array}$ & $\begin{array}{l}-0.117^{* *} \\
(0.048)\end{array}$ & $\begin{array}{l}-0.102^{* * *} \\
(0.031)\end{array}$ & $\begin{array}{l}-0.093^{* * *} \\
(0.024)\end{array}$ & $\begin{array}{l}-0.008 \\
(0.037)\end{array}$ \\
\hline Pension income incentive & $\begin{array}{l}0.507^{* * *} \\
(0.029)\end{array}$ & $\begin{array}{l}0.458^{* * *} \\
(0.022)\end{array}$ & $\begin{array}{l}0.396^{* * *} \\
(0.029)\end{array}$ & $\begin{array}{l}0.517^{* * *} \\
(0.030)\end{array}$ & $\begin{array}{l}0.470^{* * *} \\
(0.023)\end{array}$ & $\begin{array}{l}0.402^{* * *} \\
(0.032)\end{array}$ & $\begin{array}{l}0.512^{* * *} \\
(0.028)\end{array}$ & $\begin{array}{l}0.464^{* * *} \\
(0.021)\end{array}$ & $\begin{array}{l}0.399 * * * \\
(0.029)\end{array}$ \\
\hline $\begin{array}{l}\text { Gradual retirement*Pension } \\
\text { income incentive }\end{array}$ & $\begin{array}{l}-0.002 \\
(0.043)\end{array}$ & $\begin{array}{l}-0.007 \\
(0.035)\end{array}$ & $\begin{array}{l}0.034 \\
(0.056)\end{array}$ & $\begin{array}{l}-0.124^{* * *} \\
(0.039)\end{array}$ & $\begin{array}{l}-0.107^{* * *} \\
(0.031)\end{array}$ & $\begin{array}{l}-0.023 \\
(0.047)\end{array}$ & $\begin{array}{l}-0.063^{* *} \\
(0.031)\end{array}$ & $\begin{array}{l}-0.057^{* *} \\
(0.024)\end{array}$ & $\begin{array}{l}0.005 \\
(0.038)\end{array}$ \\
\hline Constant & $\begin{array}{l}65.226^{* * *} \\
(0.191)\end{array}$ & $\begin{array}{l}64.921^{* * *} \\
(0.156)\end{array}$ & $\begin{array}{l}65.269^{* * *} \\
(0.150)\end{array}$ & $\begin{array}{l}65.240^{* * *} \\
(0.183)\end{array}$ & $\begin{array}{l}64.998^{* * *} \\
(0.146)\end{array}$ & $\begin{array}{l}65.222^{* * *} \\
(0.142)\end{array}$ & $\begin{array}{l}65.233^{* * *} \\
(0.183)\end{array}$ & $\begin{array}{l}64.960^{* * *} \\
(0.147)\end{array}$ & $\begin{array}{l}65.245^{* * *} \\
(0.139)\end{array}$ \\
\hline Observations & 3552 & 4902 & 2106 & 3552 & 4902 & 2106 & 3552 & 4902 & 2106 \\
\hline R-squared & 0.132 & 0.127 & 0.168 & 0.229 & 0.234 & 0.294 & 0.089 & 0.080 & 0.116 \\
\hline
\end{tabular}

Note: OLS estimates, including robust standard errors corrected for clustering on the individual level, are in parentheses. ${ }^{* * *} p<.01$, ${ }^{* *} p<.05,{ }^{*} p<.1$.

pension income incentives to postpone retirement are, as could be expected, ranked lower. Finally, the analysis including the interactions between gradual retirement and the two financial incentives shows that workers especially dislike the scenario that includes a combination of gradual retirement and price of leisure incentives. This could be due to the fact that, in the gradual retirement regime, workers already pay a higher price (in terms of lower replacement rates) for more leisure time.

The results of our ranking analysis are thus not in line with our expectation that the introduction of gradual retirement opportunities would lead to substantially different retirement patterns (Reday-Mulvey and Delsen 1996; Reday-Mulvey 2000). However, our results are consistent with other studies which showed that many workers are more likely to choose full retirement over partial retirement (Van Soest et al. 2006; Kantarci and Van Soest 2013). ${ }^{19,20}$

\subsection{Heterogeneity in preferences: the role of age}

In this subsection, we examine the effects of gradual retirement by subject age. Such analysis helps to assess the validity of our results. Workers enrolled in the study were born between 1952 and 1975. As the experiment was conducted in 2016 , the age range of the workers in our sample was 41 to 64 . The oldest respondents were thus very close to deciding whether to retire, while the youngest workers still had to work for approximately 25 more years. We could therefore expect that older workers have more precise preferences regarding their retirement than younger workers.

Table 9 shows OLS regressions of the heterogeneous treatment effects by age group: workers who are 55 years or younger, workers aged 56-59, and those aged 60 years or older. This table shows that the differences in the impact of gradual retirement by age group are extremely small. We do find that workers aged 60 years or older postpone their fulltime retirement by 1.6 months less when they have the gradual retirement option compared to workers who are 55 years and younger. This effect is only marginally statistically significant. However, we also observe that there is no significant difference in the effect of gradual retirement on the overall labour supply between the age groups. Our results thus show that Dutch middle age individuals are very forward looking, with similar thinking about their retirement as older individuals.

\subsection{Heterogeneity in preferences: The role of health and heavy physical work}

One of the most frequently mentioned arguments in the policy debate in favour of introduction of gradual retirement is that reduction in work hours reduces the burden of work for employees with health problems. Moreover, it may reduce the burden of work for those who are employed in physically demanding jobs for which the need for recovery is greater.

\footnotetext{
19 We replicated our main analyses separately for the government sector, the education sector, and employees of privatized organizations (among others, major utility and transport companies) in our estimation sample. In total, $43 \%$ of all employees are employed in the education sector, $39 \%$ in the government sector, and $18 \%$ are employed in the privatized sector. Table A5 shows that the results are similar for the various sectors. This boosts confidence in the relevance of our results for the private sector.

20 Table A6 presents the results of regression analyses on retirement age and the full-time equivalent age of retirement, where we make a selection on the first choice in the ranking analysis. By selecting exclusively on the first choice in the ranking analysis, our results are likely to be more closely related to revealed preferences, as we can assume that people in real life are more likely to pick their most preferred choice. We find that the impact of gradual retirement does not differ from our basic results. This implies that our results may be closely related to workers' actual choices. Moreover, the fact that we do not find significantly different results provides additional suggestive evidence that participants in our survey consistently answered the vignettes, even when the presented scenarios did not include their preferred choice.
} 
Table 10

Gradual retirement: a heterogeneity analysis.

\begin{tabular}{|c|c|c|c|c|c|c|c|c|c|}
\hline \multirow[b]{3}{*}{ Gradual retirement } & (1) & $(2)$ & (3) & (4) & (5) & (6) & (7) & $(8)$ & (9) \\
\hline & \multicolumn{3}{|c|}{ Full-time retirement age } & \multicolumn{3}{|c|}{$\begin{array}{l}\text { First observed retirement age } \\
\text { (full-time or part-time) }\end{array}$} & \multicolumn{3}{|c|}{$\begin{array}{l}\text { Full-time-equivalent age of } \\
\text { retirement }\end{array}$} \\
\hline & $\begin{array}{l}0.849 * * * \\
(0.058)\end{array}$ & $\begin{array}{l}0.951^{* * *} \\
(0.027)\end{array}$ & $\begin{array}{l}0.828^{* * *} \\
(0.060)\end{array}$ & $\begin{array}{l}-1.600^{* * *} \\
(0.057)\end{array}$ & $\begin{array}{l}-1.565^{* * *} \\
(0.027)\end{array}$ & $\begin{array}{l}-1.614^{* * *} \\
(0.058)\end{array}$ & $\begin{array}{l}-0.375^{* * *} \\
(0.047)\end{array}$ & $\begin{array}{l}-0.307^{* * *} \\
(0.020)\end{array}$ & $\begin{array}{l}-0.393^{* * *} \\
(0.048)\end{array}$ \\
\hline Price of leisure incentive & $\begin{array}{l}0.589^{* * *} \\
(0.044)\end{array}$ & $\begin{array}{l}0.617^{* * *} \\
(0.020)\end{array}$ & $\begin{array}{l}0.602 * * * \\
(0.045)\end{array}$ & $\begin{array}{l}0.517^{* * *} \\
(0.039)\end{array}$ & $\begin{array}{l}0.503^{* * *} \\
(0.017)\end{array}$ & $\begin{array}{l}0.528^{* * *} \\
(0.040)\end{array}$ & $\begin{array}{l}0.553^{* * *} \\
(0.037)\end{array}$ & $\begin{array}{l}0.560^{* * *} \\
(0.016)\end{array}$ & $\begin{array}{l}0.565^{* * *} \\
(0.038)\end{array}$ \\
\hline Pension income incentive & $\begin{array}{l}0.431^{* * *} \\
(0.052)\end{array}$ & $\begin{array}{l}0.476^{* * *} \\
(0.020)\end{array}$ & $\begin{array}{l}0.446^{* * *} \\
(0.053)\end{array}$ & $\begin{array}{l}0.406^{* * *} \\
(0.048)\end{array}$ & $\begin{array}{l}0.427^{* * *} \\
(0.017)\end{array}$ & $\begin{array}{l}0.413^{* * *} \\
(0.050)\end{array}$ & $\begin{array}{l}0.419^{* * * *} \\
(0.047)\end{array}$ & $\begin{array}{l}0.452^{* * *} \\
(0.016)\end{array}$ & $\begin{array}{l}0.429 * * * \\
(0.048)\end{array}$ \\
\hline Bad health & $\begin{array}{l}-0.322^{* * *} \\
(0.117)\end{array}$ & & $\begin{array}{l}-0.340^{* * *} \\
(0.117)\end{array}$ & $\begin{array}{l}-0.292^{* * *} \\
(0.110)\end{array}$ & & $\begin{array}{l}-0.308^{* * *} \\
(0.110)\end{array}$ & $\begin{array}{l}-0.307^{* * *} \\
(0.112)\end{array}$ & & $\begin{array}{l}-0.324^{* * *} \\
(0.112)\end{array}$ \\
\hline Gradual retirement*bad health & $\begin{array}{l}0.159^{* *} \\
(0.066)\end{array}$ & & $\begin{array}{l}0.156^{* *} \\
(0.067)\end{array}$ & $\begin{array}{l}0.059 \\
(0.065)\end{array}$ & & $\begin{array}{l}0.060 \\
(0.065)\end{array}$ & $\begin{array}{l}0.109 * * \\
(0.053)\end{array}$ & & $\begin{array}{l}0.108 * * \\
(0.054)\end{array}$ \\
\hline Price of leisure incentive*bad health & $\begin{array}{l}0.011 \\
(0.052)\end{array}$ & & $\begin{array}{l}0.019 \\
(0.052)\end{array}$ & $\begin{array}{l}-0.037 \\
(0.046)\end{array}$ & & $\begin{array}{l}-0.031 \\
(0.046)\end{array}$ & $\begin{array}{l}-0.013 \\
(0.045)\end{array}$ & & $\begin{array}{l}-0.006 \\
(0.044)\end{array}$ \\
\hline Pension income incentive*bad health & $\begin{array}{l}0.042 \\
(0.061)\end{array}$ & & $\begin{array}{l}0.040 \\
(0.061)\end{array}$ & $\begin{array}{l}0.023 \\
(0.057)\end{array}$ & & $\begin{array}{l}0.019 \\
(0.057)\end{array}$ & $\begin{array}{l}0.032 \\
(0.055)\end{array}$ & & $\begin{array}{l}0.030 \\
(0.056)\end{array}$ \\
\hline Physically demanding tasks & & $\begin{array}{l}0.024 \\
(0.102)\end{array}$ & $\begin{array}{l}0.042 \\
(0.102)\end{array}$ & & $\begin{array}{l}0.004 \\
(0.097)\end{array}$ & $\begin{array}{l}0.021 \\
(0.097)\end{array}$ & & $\begin{array}{l}0.014 \\
(0.098)\end{array}$ & $\begin{array}{l}0.032 \\
(0.098)\end{array}$ \\
\hline $\begin{array}{l}\text { Gradual retirement* physically } \\
\text { demanding tasks }\end{array}$ & & $0.109 *$ & 0.106 & & 0.046 & 0.046 & & 0.078 & 0.076 \\
\hline $\begin{array}{l}\text { Price of leisure incentive* physically } \\
\text { demanding tasks }\end{array}$ & & $\begin{array}{l}-0.062 \\
(0.053)\end{array}$ & $\begin{array}{l}-0.075 \\
(0.052)\end{array}$ & & $\begin{array}{l}-0.055 \\
(0.047)\end{array}$ & $\begin{array}{l}-0.067 \\
(0.045)\end{array}$ & & $\begin{array}{l}(0.051) \\
-0.059 \\
(0.046)\end{array}$ & $\begin{array}{l}(0.051) \\
-0.071 \\
(0.044)\end{array}$ \\
\hline $\begin{array}{l}\text { Pension income incentive* physically } \\
\text { demanding tasks }\end{array}$ & & $\begin{array}{l}-0.045 \\
(0.052)\end{array}$ & $\begin{array}{l}-0.052 \\
(0.052)\end{array}$ & & $\begin{array}{l}-0.012 \\
(0.049)\end{array}$ & $\begin{array}{l}-0.016 \\
(0.049)\end{array}$ & & $\begin{array}{l}-0.029 \\
(0.047)\end{array}$ & $\begin{array}{l}-0.034 \\
(0.047)\end{array}$ \\
\hline Constant & $\begin{array}{l}65.348^{* * *} \\
(0.140)\end{array}$ & $\begin{array}{l}65.087^{* * *} \\
(0.104)\end{array}$ & $\begin{array}{l}65.350^{* * *} \\
(0.142)\end{array}$ & $\begin{array}{l}65.429^{* * *} \\
(0.131)\end{array}$ & $\begin{array}{l}65.201^{* * *} \\
(0.097)\end{array}$ & $\begin{array}{l}65.438^{* * *} \\
(0.132)\end{array}$ & $\begin{array}{l}65.388^{* * *} \\
(0.133)\end{array}$ & $\begin{array}{l}65.144^{* * *} \\
(0.098)\end{array}$ & $\begin{array}{l}65.394^{* * *} \\
(0.135)\end{array}$ \\
\hline Observations & 10,542 & 10,518 & 10,500 & 10,542 & 10,518 & 10,500 & 10,542 & 10,518 & 10,500 \\
\hline R-squared & 0.130 & 0.129 & 0.132 & 0.238 & 0.234 & 0.239 & 0.083 & 0.080 & 0.085 \\
\hline
\end{tabular}

Note: OLS estimates, including robust standard errors corrected for clustering on the individual level, are in parentheses. ${ }^{* * *} p<.01,{ }^{* *} p<.05,{ }^{*} p<.1$.

Gradual retirement schemes may therefore have an important positive impact on the total lifetime labour supply of these particular groups of employees, as they may permit employees with health problems or who have physically demanding jobs to keep working beyond an age at which they would otherwise have fully retired.

We here analyse the extent to which introduction of gradual retirement opportunities affects differently the retirement age and the full-time equivalent retirement age of employees who are in bad health and who work in physically demanding jobs. Our health indicator is based on the following survey question: In general, how would you describe your current health? Response categories ranged from 1 (very good) to 5 (bad). A worker is defined to be in bad health if that worker's score is above the median score. Whether individuals work in a physically demanding job is measured by the following survey question:

How often do you spend time on the following task in your job? You can give your answer on a scale from 0 to 10 , where 0 means 'never' and 10 means 'always':

Physically demanding tasks (such as the lifting of patients or heavy objects or operating machinery)

Again, a worker is defined to be working in a physically demanding job when that worker has a score above the median.

Table 10 shows the OLS regressions of the heterogeneous treatment effects on workers' full-time retirement age, the first observed retirement age, and the full-time-equivalent retirement age. It becomes clear from Columns 1-3 that employees in bad health who gain access to gradual retirement postpone full-time retirement by 11.6 months, while employees in good health postpone full-time retirement by only 9.9 months. However, workers in bad health do not enter into gradual retirement earlier than workers in good health (Columns 4-6). These results thus suggest that introduction of gradual retirement indeed may reduce to some extent health-related burdens that employees with health problems may experience in carrying out their jobs. Nevertheless, introduction of gradual retirement still reduces total labour supply of both groups of workers. Columns 7-9 show that the full-time-equivalent retirement age among employees in bad health decreases by 3.4 months when they gain access to gradual retirement, while it decreases by 4.7 months among those in good health. The table further shows that workers in physically demanding jobs do retire somewhat later when they get the option to gradually retire, but this effect is not robust to the inclusion of health indicators in the estimation.

\section{Conclusion}

We use data from a stated preferences experiment to study the extent to which gradual retirement affects workers' retirement full-time age, the start date of their retirement process, and their labour supply. Some studies suggest that gradual 
retirement may not lead to a net increase in total labour supply (e.g., Gielen 2009; Machado and Portela 2012). However, these studies focus on actual retirement decisions and therefore do not identify all retirement options available to older workers, because the options that are not chosen cannot be observed, or because it is not clear which options could have been chosen by workers (Kantarci and Van Soest 2008, 2013). A stated preferences approach solves this problem by capturing a broader array of preference-driven behaviours, and can therefore be used to estimate the causal relation between gradual retirement and a worker's age of retirement and labour supply. Concerns may arise about the external validity of retirement options in stated preference studies, especially if these retirement options do not yet exist in practice (Kantarci and Van Soest, 2013). ${ }^{21}$ However, the literature shows that stated preference estimates and estimates based on data on actual behaviour are usually quite close (Louviere et al., 2000).

We find that gradual retirement schemes, compared to full-retirement schemes, induce workers to retire approximately one year later. Lifetime labour supply of workers significantly decreases in gradual retirement systems, as the positive effect of postponing retirement on their labour supply is cancelled out by the reduction of working hours in the years before full retirement. Gradual retirement thus has an asymmetric effect on the expected timing of various retirement stages by inducing an early start to the retirement process and not postponing full-time retirement enough to generate an offsetting effect on hours worked. In particular, for the oldest workers in our estimation sample, who are close to retirement, we might expect that these expected labour supply effects would directly translate into actual labour supply effects.

We further show that financial incentives to postpone retirement (changes in the accrual rate in the pension scheme and reductions in pension income) significantly increase expected full-time retirement age. However, the impact of financial incentives on workers' retirement expectations is similar across gradual and full-retirement options. There is, however, some heterogeneity across workers in good and bad health. Employees in bad health who gain access to gradual retirement postpone their retirement age by 11.6 months, while employees in good health increase their retirement age by only 9.9 months. This result suggests that introduction of gradual retirement alleviates, as is frequently suggested in the policy debate, some of the health-related burden that employees with poor health may experience in carrying out their jobs.

From a policy perspective, introduction of gradual retirement options could be welfare enhancing, as those who prefer such an option would choose it, and those who do not would still have the option to fully retire. However, our ranking analysis of the different pension scheme scenarios shows that a large majority of workers still prefers full retirement. Moreover, our results suggest that changing current retirement schemes into gradual retirement schemes would not contribute to a further increase in labour supply. It is therefore important for policy makers to be clear on the main purpose behind introducing gradual retirement schemes. When the main aim is to postpone full retirement, for example because staying active to a later age enhances cognitive functioning and decreases the occurrence of impairments common at older ages, introduction of gradual retirement is a useful instrument. If increasing labour supply is the policy target, our results suggest that gradual retirement is not a recommended policy option.

It should be noted, however, that we identify only the effect on the labour supply of the workers in our experiment. We cannot claim that the decrease in labour supply due to gradual retirement would result in an overall reduction of employment in the economy. It could be that employees who decide to gradually retire are replaced by their employers. Whether their replacement will be through part-time or full-time employees is an important question, and partially depends on the nature of the labour market, its institutional design, and its flexibility. What matters then is the elasticity of new hiring with respect to gradual retirement, which is a rather underdeveloped topic in the literature. However, several studies (e.g., Card and Lemieux, 2001; Fitzenberger and Kohn, 2006; Gruber and Wise, 2010; Eichhorst et al., 2014; Montizaan, 2017) which focused on whether employment of older persons reduces the opportunities for employment of the young and vice versa, find no evidence that reducing/increasing the employment of older persons leads to more/less job opportunities for younger persons on the macro level. Moreover, the literature on work-sharing shows that a reduction of work hours due to work-sharing does not significantly promote employment (e.g. Kapteyn et al., 2004; Skuterud, 2007). Based on the low elasticities found in these studies, we therefore might expect that there is also an imperfect elasticity between the labour supply of workers in our 'close to retirement cohort' who start to work part-time and the job opportunities of new hires. We do concur, however, that there is not yet any research on this specific topic.

We expect that our results may be of interest for countries with retirement systems and institutional contexts similar to the Netherlands. Our results are most generalizable to Northern European countries, which have similar retirement systems, rather similar net replacement rates, and average retirement ages which closely match the Dutch situation. Generalizability will, however, be less for developing countries, the UK, and the United States, which have defined contribution schemes and considerably lower replacement rates.

\section{Acknowledgements}

We acknowledge the comments and suggestions of Hans Bloemen, Marion Collewet, Tunga Kantarci, Arjan Non, Arthur van Soest, the participants at the Fourth SOLE/EALE World Conference, Montreal, Canada, the Netspar Pension Day, Utrecht, the Netherlands, and the Netspar Pension Workshop, Leiden, The Netherlands. Fouarge and Montizaan also acknowledge the financial contribution of GAK (AOW-/pensioengerechtigden op de arbeidsmarkt) and Netspar to this research project.

\footnotetext{
21 Another limitation of our study is that we focus on public sector employees. The sectors covered are, however, large and include $13 \%$ of the total Dutch
} labour force. 


\section{Supplementary materials}

Supplementary material associated with this article can be found, in the online version, at doi:10.1016/j.jebo.2018.01.012.

\section{References}

Allen, S.G., Clark, R.L., Ghent, L.S., 2003. Phasing into retirement. Ind. Labor Relations Rev. 58, 112-127.

Barsky, R.B., Juster, F.T., Kimball, M.S., Shapiro, M.D., 1997. Preference parameters and behavioral heterogeneity: An experimental approach in the health and retirement study. Q. J. Econ. 112, 537-579.

Benjamin, D.J., Heffetz, O., Kimball, M., Szembrot, N., 2014. Beyond happiness and satisfaction: toward well-being indices based on stated preference. Am. Econ. Rev. 104 (9), 2698-2735.

Börsch-Supan, A.H., 2012. Entitlement Reforms in Europe: Policy Mixes in the Current Pension Reform Process. National Bureau of Economic Research, p. 18009. working paper.

Braga, J., Humphrey, S.J., Starmer, C., 2009. Market experience eliminates some anomalies-and creates new ones. Eur. Econ. Rev. 53 (4), $401-416$.

Card, D., Lemieux, T., 2001. Can falling supply explain the rising return to college for younger men? A cohort-based analysis. The Q. J. Econ. 116 (2), $705-746$.

De Grip, A., Lindeboom, M., Montizaan, R., 2012. Shattered dreams: the effects of changing the pension system late in the game. Econ. J. 122 (559), 1-25.

De Grip, A., Fouarge, D., Montizaan, R., 2013. How sensitive are individual retirement expectations to raising the retirement age. De Economist 161 (3), $225-251$.

Duval, R., 2005. The retirement effect of old-age pension and early retirement schemes in OECD countries. Economic Policy Reforms 2005: Going for Growth. OECD Publishing, Paris.

Eichhorst, W., Boeri, T., De Coen, A., Galasso, V., Kendzia, M., Steiber, N., 2014. How to combine the entry of young people in the labour market with the retention of older workers. IZA J. Eur. Labor Stud. 3 (1), 19.

Eifler, S., 2007. Evaluating the validity of self-reported deviant behavior using vignette analyses. Qual. Quant. 41, 303-318.

Fitzenberger, B., Kohn, K., 2006. Skill wage premia, employment, and coh IZA DP No. 2185.

Gielen, A.C., 2009. Working hours flexibility and older workers' labour supply. Oxford Econ. Papers 61 (2), $240-274$.

Gruber, J., Wise, D., 1998. Social security and retirement: an international comparison. Am. Econ. Rev. 88 (2), $158-163$.

Gruber, J., Wise, D.A., 2010. Social Security Programs and Retirement Around the World: The relationship to Youth Employment. Chicago University Press, Chicago.

Gustman, A.L., Steinmeier, T.L., 2004. Minimum Hours Constraints, Job Requirements and Retirement. National Bureau of Economic Research working paper 10876.

Graf, N., Hofer, H., Winter-Ebmer, R., 2011. Labor supply effects of a subsidized old-age part-time scheme in Austria. Zeitschrift für ArbeitsmarktForschung 44 (3), 217.

Hanel, B., 2010. Financial incentives to postpone retirement and further effects on employment-Evidence from a natural experiment. Labour Econ. 17 (3), $474-486$.

Hensher, D.A., 1997. Behavioral Value of Travel Time Savings in Personal and Commercial Automobile Travel. In: Greene, D., Jones, D., Delucchi, M. (Eds.), The Full Costs and Benefits of Transportation. Springer-Verlag, Berlin, pp. 245-280.

Hutchens, R., 2010. Worker characteristics, job characteristics, and opportunities for phased retirement. Labour Econ. 17 (6), $1010-1021$.

Hurd, M., 1996. The effect of labor market rigidities on the labor force behavior of older workers. In: Wise, D. (Ed.), Advances in the Economics of Aging. University of Chicago Press, Chicago and London, pp. 11-60.

Kangas, O., Lundberg, U., Ploug, N., 2010. Three routes to pension reform: politics and institutions in reforming pensions in Denmark, Finland and Sweden. Social Pol. Admin. 44 (3), 265-284.

Kantarci, T., Van Soest, A., 2008. Gradual retirement: Preferences and limitations. De Economist 156 (2), $113-144$

Kantarci, T., Van Soest, A., 2013. Stated Preference Analysis of Full and Gradual Retirement in the United States. Cesr-Schaeffer working paper series no. 2013-011.

Kapteyn, A., Kalwij, A., Zaidi, A., 2004. The myth of worksharing. Labour Econ. 11 (3), 293-313.

Louviere, J.J., Hensher, D.A., Swait, J.D., 2000. Stated Choice Methods: Analysis and Applications. Cambridge University Press, Cambridge.

Machado, C.S., Portela, M., 2012. Hours of work and retirement behavior. Institute for the Study of Labor discussion paper 6270.

Mastrobuoni, G., 2009. Labor supply effects of the recent social security benefit cuts: empirical estimates using cohort discontinuities. J. Public Econ. 93 (11), 1224-1233.

Montizaan, R., 2017. Post-Retirement Employment: Determinants and Labor Market Consequences Netspar survey paper 49, May.

OECD, 2015. Pensions at a Glance 2015: OECD and G20 Indicators. OECD Publishing, Paris http://dx.doi.org/10.1787/pension_glance-2015-en.

OECD, 2017. Net pension replacement rates (indicator). doi: 10.1787/4b03f028-en (Accessed on 15 February 2017).

Peabody, J., Luck, J., Glassman, P., Dresselhaus, T., Lee, M., 2000. Comparison of vignettes, standardized patients, and chart abstraction: A prospective validation study of 3 methods for measuring quality. J. Am. Med. Assoc. 283, 1715-1722.

Peabody, J., Tozija, F., Muňoz, J., Nordyke, R., Luck, J., 2004. Using vignettes to compare the quality of clinical care variation in economically divergent countries. Health Services Res. 39, 1951-1970.

Reday-Mulvey, G., 2000. Gradual retirement in Europe. J. Aging. Social Pol. 11 (2-3), 49-60.

Reday-Mulvey, G., Delsen, L., 1996. Gradual retirement in the OECD countries: A summary of the main results. Geneva Pap. Risk Insurance Issues Pract. 21 (81), 502-523.

Revelt, D., Train, K., 1998. Mixed logit with repeated choices: household choices of appliance efficiency level. Rev. Econ. Stat. 80, 647-657.

Rogers, W.H., 1993. Regression standard errors in clustered samples. Stata Tech. Bull. 13, 19-23.

Skuterud, M., 2007. Identifying the potential of work-sharing as a job-creation strategy. J. Labor Econ. 25 (2), $265-287$.

Staubli, S., Zweimüller, J., 2013. Does raising the retirement age increase employment of older workers? J. Public Econ. 108, 17-32.

Telser, H., Zweifel, P., 2007. Validity of discrete-choice experiments evidence for health risk reduction. Appl. Econ. 39, 69-78.

Van Soest, A., Vonkova, H., 2014. How sensitive are retirement decisions to financial incentives? A stated preference analysis. J. Appl. Econ. 29 (2), $246-264$.

Van Soest, A., Kapteyn, A., Zissimopoulos, J., 2007. Using Stated Preferences Data to Analyze Preferences for Full and Gradual Retirement. Institute for the Study of Labor discussion paper 2785 .

Wadensjö, E., 2006. Part-time pensions and part-time work in Sweden. Eur. Pap. New Welfare 6, 29-45.

Warren, D.A., 2015. Pathways to retirement in Australia: evidence from the HILDA Survey. Work, Aging Retirement. http://dx.doi.org/10.1093/workar-/ wau013.

Wooldridge, J.M., 2002. Econometric Analysis of Cross Section and Panel Data. MIT Press, Cambridge, MA. 